\title{
Semiotics, Analogical Legal Reasoning, and the Cf. Citation: Getting Our Signals Uncrossed
}

Ira P. Robbins

American University Washington College of Law, robbins@wcl.american.edu

Follow this and additional works at: https://digitalcommons.wcl.american.edu/facsch_lawrev

Part of the Legal Writing and Research Commons

\section{Recommended Citation}

Ira P. Robbins, Semiotics, Analogical Legal Reasoning, and the Cf. Citation: Getting Our Signals Uncrossed, 48 Duke Law Journal (1999).

Available at: https://digitalcommons.wcl.american.edu/facsch_lawrev/1029

This Article is brought to you for free and open access by the Scholarship \& Research at Digital Commons @ American University Washington College of Law. It has been accepted for inclusion in Articles in Law Reviews \& Other Academic Journals by an authorized administrator of Digital Commons @ American University Washington College of Law. For more information, please contact kclay@wcl.american.edu. 


\title{
SE MIOTICS, A NA LOG ICA L LEGAL \\ REASONING, AND THE Cf. CITATION: GETTING OUR SIG NALS UNCR OSSE D
}

\author{
IRA P. ROBBINSt
}

\begin{abstract}
A BSTRACT
The Bluebook's introductory citation signals are essential to effective legal discourse. The choice of signal can influence not only the interpretation of cited cases, but also the path of the law. In this A rticle, Professor Ira Robbins examines one commonly used signal: the cf. A fter exploring its semiotic function, he details the multitude of ways in which this signal has been used and misused. He argues that lawyers' and judges' careless use of the cf. leads to confusing and often incoherent developments in the law, and concludes by proposing a precise working definition for this irksome, but potentially powerful, citation signal.
\end{abstract}

\section{INTRODUCTION}

L egal writers often complain about the form of legal discourse to the point where seemingly inconsequential esoterica receive the passionate scrutiny of the well-intentioned analyst. ${ }^{1}$ B ut introductory signals- which may be the epitome of form-draw considerable fire for good reason: they are often poorly defined, prompting both inconsistent usage and great confusion. ${ }^{2}$

Copyright @ 1999 by I ra P. R obbins. A II rights reserved.

† Barnard T. Welsh Scholar and Professor of Law and J ustice, A merican U niversity, Washington College of Law; A.B. 1970, U niversity of Pennsylvania; J.D. 1973, Harvard U niversity. I am grateful to my colleague Michael Tigar for taking the time to read and comment on an earlier draft of this A rticle. I also thank J oshua S. Millard and A ndrea S. Tisi for their excellent research assistance and the A merican U niversity L aw School R esearch Fund for providing financial support.

1. See, e.g., Fred R odell, G oodbye to L aw Reviews, 23 V A. L. REV. 38, 38 (1936) (stating that the only two things wrong with law review articles are their style and their content); Fred Rodell, Comment, Goodbye to L aw Reviews-Revisited, 48 VA. L. REV. 279, 289 (1962) (describing footnotes as "phony excrescences").

2. J udicial opinions refer to The B luebook rules regarding introductory signals more than to any other citation rules. See A. Darby Dickerson, An Un-Uniform System of Citation: Surviving with the New Bluebook (Including Compendia of State and Federal Court Rules Concerning Citation Form), 26 STETSON L. REV. 53, 68 (1996). This A rticle analyzes selected 
While their definitions may be poor, however, introductory signals clearly serve two major purposes: they "indicate the purposes for which the citations are made and the degree of support the citations give." ${ }^{3}$ O ther meanings may exist, of course. For example, two authors have suggested that academic legal citation also fulfills the obligation to indicate familiarity with certain authorities and may signal a group identity or theoretical perspective. ${ }^{4}$ A nother commentator has sought to determine whether judicial citation seeks primarily to justify certain results rather than to explain the actual reasoning behind decisions. ${ }^{5} \mathrm{~A}$ Iternatively, perhaps we simply expect too much from legal citation signals. ${ }^{6}$

$O$ ne attribute of introductory signals is paramount: in subtle and sometimes not-so-subtle ways, they help to determine the future direction of the law. Thus, to the extent that the signals are defined

judicial interpretations of ambiguous cf. cites. See infra Part II. N umerous legal commentators have also criticized introductory signals, often while reviewing the latest citation manual. See, e.g., Richard L. Bowler, Book R eview, 44 U. CHI. L. REV. 695, 700 (1977) (reviewing A Uniform Sy Stem OF CitATION (Columbia Law Review Ass'n et al. eds., 12th ed. 1976)); $M$ ary I. Coombs, Lowering O ne's Cites: A (Sort Of) Review of the University of Chicago Manual of Legal Citation, 76 VA. L. REV. 1099, 1106-11 (1990); Dickerson, supra, at 68-70; Peter Lushing, A Uniform System of Citation, 67 CoLUM. L. REV. 599 (1967) (reviewing A U NIFORM SYSTEM OF CITATION (Columbia Law Review A ss'n et al. eds., 11th ed. 1967)); Peter Phillips, B ook Note, A Uniform System of Citation, 32 N.Y.L. SCH. L. RE V. 199, 199-200 (1987) (reviewing A U NIFORM SY STEM OF CITA TION (Columbia Law R eview A ss'n et al. eds., 14th ed. 1986)). Such criticism may reflect the practice of what two authors have termed, perhaps ironically, "[c]itology, the study of citations." J.M. Balkin \& Sanford L evinson, H ow to Win Cites and Influence People, 71 CHI.-KENT L. REV. 843, 843 (1996); see also Dickerson, supra, at 66-70 (reviewing several changes in signal definitions and arguing that similar changes "destroy any hope of building a truly uniform citation system"); James W. Paulsen, An U ninformed System of Citation, 105 H A R V. L. REV . 1780, 1791 (1992).

3. The Bluebook: A Uniform System of Citation Rule 1 (Columbia Law Review A ss'n et al. eds., 16th ed. 1996) [hereinafter BLUEBOOK SIXTEEN]. It is also generally agreed that legal citations "give credit for borrowed material," William R. Slomanson, Footnote L ogic in L aw Review Writing: Previously U naddressed in the Criminal J ustice System, 9 CR IM . J U ST. J . 65, 68 (1986), and "allow the reader to locate a cited source accurately and efficiently," BLUEBOOK SIXTEEN, supra, at I.2.

4. See B alkin \& Levinson, supra note 2 , at 860-61, 868.

5. See $D$ avid J. Walsh, On the M eaning and Pattern of L egal Citations: Evidence from State Wrongful Discharge Precedent Cases, 31 L. \& SoC. REV. 337 (1997). Walsh provides a valuable overview of social science studies examining the function that citation serves in judicial opinions. See id.

6. J udge Wilfred Feinberg, using the eleventh edition of The Bluebook, summed up the inherent ambiguity in employing any introductory signal: "Such substantive reliance on citation forms suggests too much for the 'glorious inscrutibility' [sic] of introductory signals." B eaney v. U nited States, 271 F. Supp. 692, 696 (W.D.N.Y. 1967) (misquoting L ushing, supra note 2, at 601). 
incorrectly or used imprecisely, they affect the analogical reasoning process that is at the foundation of common law jurisprudence.

While there are numerous introductory citation signals- many susceptible to broad criticisms and that merit further analysis ${ }^{7}$ - this A rticle focuses on the cf. signal. B ecause it is the weakest of the citation signals that indicate support (according to The Bluebook ${ }^{8}$ ), it is the most intellectually challenging one. It is also the least well understood signal; thus, it is in the greatest need of increased precision.

L ambrix v. Singletary, ${ }^{9}$ a recent Supreme Court opinion, demonstrates the potential ramifications of citing a case with the $\mathrm{cf}$. signal. Capital prisoner Cary M ichael Lambrix's death sentence hung on the interpretation of the cf. The case presented the question whether Lambrix could successfully challenge his sentence because the aggravating factors considered by the jury were later ruled

7. This A rticle focuses on the cf. signal. However, the see signal could also use further analysis, as several decisions demonstrate. Compare Schmidt v. M cCarthy, 369 F.2d 176, 182 n.18 (D.C. Cir. 1965) (noting the court's use of the see signal in M ilone v. English, 306 F.2d 814 (D.C. Cir. 1962), and explaining that it was used "to indicate that 'the asserted opinion or conclusion will be suggested by an examination of the cited authority'" (quoting A U NIFORM SYSTEM OF CITATION 27:2:3 (Columbia Law Review Ass'n et al. eds., 10th ed. 1958) [hereinafter BLUEBOOK TEN]) with National Org. for Women, Inc. v. Scheidler, 897 F. Supp. 1047, 1062 n.14 (N.D. III. 1995). In Scheidler, the court stated that "this court need not follow the letter of the Seventh Circuit's ruling and assume, without analysis, that section 1367 applies because of the 'see' signal." Id. at 1062 n.14. It interpreted the see signal as "directing the reader's attention to the statute to show the general legal theory supporting its conclusion that the counts were to be reinstated." Id.

Scheidler points up another problem with changing definitions of signals. In one edition of The Bluebook, the see signal may be used to suggest an inferential step between the authority and the proposition offered, while [no signal] is used to introduce "on point" authority. See BLUEBOOK TEN, supra, 27:2. By contrast, the sixteenth edition uses see to show direct support while reserving [no signal] to identify sources or attribute quotes. See BLUEBOOK SIXTEEN, supra note 3, R ule 1.2(a). In Scheidler, the district court interpreted see as indirect support akin to see generally. See Scheidler, $897 \mathrm{~F}$. Supp at 1062; see also B eaney, $271 \mathrm{~F}$. Supp. at 696; State v. OItmanns, 519 N.W .2d 602, 606 (S.D. 1994) (Henderson, J ., concurring) (criticizing the majority's use of compare to give more weight to a dissent than it merited).

The change regarding the see signal alone ought to prompt considerable controversy, for not only can evolving definitions lead to confusion in interpretation of signal use, see $D$ onald $H$. Gjerdingen, A Uniform System of Citation, 4 WM. MITCHELL L. REV. 499, 510 (1978) (reviewing A UNIFORM SY STEM OF CITATION (Columbia Law Review A ss'n et al. eds., 12th ed. 1976)) ("The tragedy is that one edition's signals are meaningless to a person schooled in a different edition."), but also the new use of the see signal may not be an improvement over earlier uses.

8. The cf. signal is listed last among the introductory signals "that indicate support" in The Bluebook. BLUEB OOK SIXTEEN, supra note 3, R ule 1.2(a).

9. 520 U .S. 518 (1997). 
unconstitutional in a different case. ${ }^{10} E$ ight years before $L$ ambrix, the Court's general holding in Teague $v$. $L$ ane ${ }^{11}$ had forbidden retroactive application of "new" constitutional rules of criminal procedure to final convictions on collateral review. ${ }^{12}$ The $L$ ambrix Court decided that its later ruling in Espinosa v. Florida ${ }^{13}$ was not available to $L$ ambrix because it was a new rule not dictated by existing precedent and the Constitution at the time his conviction became final. ${ }^{14}$ E mphasizing that E spinosa's conclusion was not compelled by extant precedent, J ustice Scalia observed:

The [E spinosa] opinion cited only a single case, B aldwin v. A labama, 472 U.S. 372, 382 (1985), in support of its central conclusion that indirect weighing of an invalid aggravator "creates the same potential for arbitrariness" as direct weighing of an invalid aggravator. And it introduced that lone citation with a "cf." - an introductory signal which shows authority that supports the point in dictum or by analogy, not one that "controls" or "dictates" the result. ${ }^{15}$

Baldwin, however, arguably did establish that the Court's ruling in Espinosa was not an unprecedented leap of reason. ${ }^{16}$ Curiously, neither of the two $L$ ambrix dissents defended the citation to $B$ aldwin.

The fact that E spinosa introduced Baldwin with a cf. signal helps explain why the Lambrix majority failed to analyze potentially contradictory Supreme Court statements concerning the novelty of the principle it propounded. A s exemplified in L ambrix, cf. citations are frequently used but rarely, if ever, explained. M oreover, they are often viewed with skepticism. O ne observer has even speculated that

10. See id. at 518.

11. 489 U .S. 288 (1989).

12. See id. at 310 .

13. 505 U .S. 1079, 1081 (1992) (per curiam) (“[A ]n aggravating circumstance is invalid in this sense if its description is so vague as to leave the sentencer without sufficient guidance for determining the presence or absence of the factor. We have held instructions more specific and elaborate than the one given in the instant case unconstitutionally vague." ).

14. See L ambrix, 520 U .S. at 539-40.

15. Id. at 529 (emphasis added) (citation omitted) (quoting E spinosa, 505 U .S. at 1082).

16. The B aldwin Court stated that a defendant's argument "conceivably might have merit if the judge actually were required to consider the jury's 'sentence' as a recommendation as to the sentence the jury believed would be appropriate, and if the judge were obligated to accord some deference to it." B aldwin v. A labama, 472 U.S. 372, 382 (1985) (citation omitted). The E spinosa case originated in Florida, a state that requires its judges "to pay deference to a jury's sentencing recommendation." Espinosa, 505 U.S. at 1082. Intriguingly, the Baldwin Court itself cited Proffitt v. Florida, 428 U .S. 242 (1976), with a cf. signal to support the first sentence quoted above. See B aldwin, 472 U .S. at 382. 
legal writers use the cf. signal when they wish to impress the reader with the breadth of their research. ${ }^{17}$ F or those who have not read or had experience with the citation rules, the process of interpreting such carelessly used citations can be either exasperating or completely cryptic. ${ }^{18}$ Expert legal writers often fare no better, and many have found fault with the use and misuse of the cf. signal. ${ }^{19}$ E minent jurist Robert Bork, for example, offered the following reprobation: "As the majority presumably recognized, since it cited [a prior decision] with a cf., the case is probably inapposite." ${ }^{20}$ W hat, then, is the true value of the cf. signal? This A rticle attempts to answer that question from a semiotic perspective, examining how the cf. signal may operate in both theory and practice.

In Part I, this A rticle presents a history of the meaning and use of the cf. signal, with particular reference to semiotics as a theoretical construct through which to evaluate it. Part II takes this theoretical construct and applies it to a variety of judicial decisions that use and analyze the cf. citation. In addition, Part II highlights the spectrum of cf. decisions, and the implications of the ambiguity and contradiction in the use of this signal. Finally, Part III integrates theory and judicial practice and proposes an approach to cf. usage that should lead to greater clarity and understanding. case.").

17. See L ushing, supra note 2 , at 601 (" $\mathrm{U}$ se cf. when you've wasted your time reading the

18. See Frederick Bernays Weiner, Briefing and Arguing Federal A ppeals 223 (2d ed. 1961) (describing introductory signals as "a virtually cryptographic code"); Coombs, supra note 2, at 1110 ("[T] he standard citations forms have the virtue of using linguistic ambiguity to avoid confronting delicate theoretical or political issues.").

19. The quarrels are often quite contentious. See Czerkies v. U nited States Dep't of Labor, 73 F.3d 1435, 1447 (7th Cir. 1996) (en banc) (E asterbrook, J., concurring) ("Rodrigues gave [the case cited by the Ninth Circuit] a 'cf.' citation; the correct signal would have been "contra.'"). Incidentally, The Bluebook no longer includes the contra signal in its list of signals. Compare The Bluebook: A Uniform System of Citation Rule 1.2(a) (Columbia Law Review A ss'n et al. eds., 15th ed. 1991) [hereinafter BLUEBook FIfTEEN] Rule 1.2(c), with BLUEBOOK SIXTEEN, supra note 3, Rule 1.2(c). Under the fifteenth edition, one would use contra when the "[C]ited authority directly states the contrary of the proposition." BLUEBOOK FifteEn, supra, 1.2(c).

20. H ohri v. U nited States, 793 F.2d 304, 312 n.4 (D.C. Cir. 1986) (Bork, J., joined by Scalia, Starr, Silberman, \& Buckley, JJ., dissenting from denial of petition for rehearing en banc). 


\section{A. A nalogical R easoning and the Problem of $C f$. D efinition}

F ew readers of law journals require an education in the meaning of reasoning by analogy. Both law students and judges (as well as many lawyers) engage in the process daily. Suffice it to say for present purposes, therefore, that, in every case necessitating the application of law to fact, the judge must determine the extent to which existing precedent governs the instant case. If the court deems the precedent to be "close," the court will treat the precedent either as controlling or as influential and apply it to the case accordingly. If, on the other hand, the court focuses on one or more factors to distinguish existing precedent, then the court will either have to find closer precedent or treat the case as one of first impression and formulate an appropriate rule of decision.

This notion of "closeness" - or degree of separation-is inherent in the process of analogical reasoning. J udges, through their opinions, move in interstitial ways. ${ }^{21}$ This notion of closeness is also inherent in legal citation practice, for introductory signals "indicate the purposes for which the citations are made and the degree of support the citations give." ${ }^{22}$ In this way, citation signals help to pave the path of the law. By helping to assign the degree of support and the strength of distinctions and reconciliations, they help to articulate the degree of departure from existing law. If the signposts are bad, so too may be the destination. We must therefore take utmost care to be true to the intended development of the law. Put differently, careless citation practice can lead to haphazard consequences that should be controlled to the extent desired and to the extent possible.

D espite the laudable goals of citation practice, the of. signal is viewed with skepticism. O ne reason is that practical definitions and uses of the signal vary widely. The Bluebook authors explicitly grant

21. See, e.g., Southern Pac. Co. v. Jensen, 244 U.S. 205, 221 (1917) (Holmes, J., dissenting) ("I recognize without hesitation that judges do and must legislate, but they can do so only interstitially; they are confined from molar to molecular motions."); BENJAMIN N. CARdozo, The NATURE OF THE Judicial Process 103 (1921) (“We must keep within those interstitial limits which precedent and custom and the long and silent and almost indefinable practice of other judges through the centuries of the common law have set to judge-made innovations.").

22. BLUebook SiXteen, supra note 3, Rule 1. 
the $\mathrm{cf}$. signal the terrain of analogical legal reasoning. ${ }^{23} 0$ ther writers implicitly do the same, reserving cf. for cited authorities that involve substantially different facts, ${ }^{24}$ law, ${ }^{25}$ or both. ${ }^{26}$ Black's L aw D ictionary effectively portrays the cf. as a catchall for any point the author wishes to make. ${ }^{27} \mathrm{Cf}$. might be short for "cipher" - it is a nebulous introductory signal, practically devoid of meaning without further explanation by the author ${ }^{28}$ Or cf. might simply mean "can't find": aware that a particular proposition requires support, the author, unable to locate anything close, just cites a book, article, or case that is "close enough."

A nother reason that the $\mathrm{cf}$. signal may attract criticism is that different generations of lawyers and authors remember it differently

23. The authors of The Bluebook first made passing reference to analogical reasoning under the of. signal more than forty years ago. See A U NIFORM SY STEM OF CITATION, Rule VIII(A )(1)(d) (Columbia L aw R eview A ss'n et al. eds., 9th ed. 1955) (stating that the cf. signal should be used "before a case, statute, or secondary [authority] expressing a legal proposition which, while only analogous, lends some support for the statement, conclusion, or opinion of law in text").

24. See Miles O. Price \& Harry Bitner, Effective Legal Research 389 (3d ed. 1969) ("Where the dictum, though deriving from substantially different facts, is sufficiently in point to be cited in the discussion, substitute italicized ' $\mathrm{Cf}$.' for 'See.'"). The tenth edition of The Bluebook linked the cf. signal to authorities that discussed different facts and law, but the factrelated portion of its definition is particularly striking: "'Cf.,' rather than 'accord,' is appropriate whenever a factual distinction between the text and the authority is of such legal significance that the proposition of law must be materially different." BLUEBOOK TEN, supra note 7 , R ule $27: 2: 4$

25. See Casey v. Transamerica L ife Ins. \& A nnuity Co., 511 F.2d 577, 582 (7th Cir. 1975) (Pell, J., dissenting) (evaluating the use of a cf. citation to a similar factual situation analyzed under discrete law and stating that " $[\mathrm{t}] \mathrm{he}$ case . . . is properly cited with a 'Cf.' reference because it is not[, like the present controversy,] a reinstatement case"); J OYCE J. GEORGE, JUDICIAL OPINION WRITING HANDBOOK 252 (3d ed. 1993) (defining cf. as "[a]n abbreviation for confer which translates into 'compare' and indicates that while the material cited lends support to the proposition advanced, it is directed to another point"); see also A laska v. Federal E nergy R egulatory Comm'n, 980 F.2d 761, 763 (D.C. Cir. 1992) (approving cf. use where "[t]he theory underlying both decisions is the same").

26. See L ambrix v. Singletary, 520 U .S. 518, 529 (1997) (describing cf. as “an introductory signal which shows authority that supports the point in dictum or by analogy, not one that "controls' or 'dictates' the result"); MILES O. PRICE, A PRACTICAL MANUAL OF STANDARD LEGAL CITATIONS 58 (1958) (employing a definition nearly identical to that present in PRICE $\&$ BITNER, supra note 24 , at 389 , with the exception of a parenthetical: "W here the dictum in a cited case, though deriving from substantially different facts (or the case is otherwise distinguishable from the situation being discussed), is sufficiently in point....") (emphasis added)).

27. See BLACK'S LAW DICTIONARY 229 (6th ed. 1990) (defining cf. as a signal that "[d]irects the reader's attention to another part of the work, to another volume, case, etc., where contrasted, analogous, or explanatory views or statements may be found").

28. See Bluebook Sixteen, supra note 3, Rule 1.2(a) ("The citation's relevance will usually be clear to the reader only if it is explained."). 
and therefore use it differently. The authors of The Bluebook altered its definition-albeit subtly -almost every time the manual was printed between 1947 and $1996 .{ }^{29}$ For example, the seventh edition of The Bluebook, printed in 1947, recommended the cf. signal when a case "is parallel to the proposition for which it is cited but contains facts materially different." ${ }^{30}$ Eight years later, the ninth edition suggested using cf. "before a case, statute, or secondary [authority] expressing a legal proposition which, while only analogous, lends some support for the statement, conclusion, or opinion of law in text." ${ }^{31}$ In 1958, the tenth edition made more extensive changes:

"Cf." is used to introduce any authority which supports a statement, conclusion, or opinion of law different from that in text but sufficiently analogous to lend some support to the text. "Cf." is never used to support a statement of fact.

"Cf.," rather than "accord," is appropriate whenever a factual distinction between the text and the authority is of such legal significance that the proposition of law must be materially different. "Cf.," rather than "see," is appropriate whenever the proposition supported by the authority is not relevant directly to that advanced by text but only analogous to it. ${ }^{32}$

The eleventh edition included an only slightly reworded version of the first sentence contained in the tenth edition, ${ }^{33}$ and eliminated the second paragraph entirely. The thirteenth edition added a new sentence, one directly relevant to the present discussion: "The [cf.] citation's relevance will usually be clear to the reader only if it is

29. See Dickerson, supra note 2 , app. C-1 at 212; id. at 67 (listing introductory signal definitions from the fifteenth and sixteenth editions of The Bluebook); id. at $55 \mathrm{n.1}$ (identifying the dates of publication for the seventh edition, which commenced the practice of defining introductory signals, and the fourteenth edition, which contained the most recent adjustment). $L$ aw journals introduced the $\mathrm{cf}$. signal, which had little legal tradition prior to its introduction in the first half of the century. See WEINER, supra note 18, at 223.

30. A U NIFORM SYSTEM OF CITATION (Columbia Law Review A ss'n et al. eds., 7th ed. 1947); see also Dickerson, supra note 2, app. C-1 at 212.

31. A Uniform System of Citation (Columbia Law Review A ss'n et al. eds., 9th ed. 1955); see also D ickerson, supra note 2, app. C-1 at 214. at 215 .

32. BLUEBOOK TEN, supra note 7, R ule 27:2:4; see also Dickerson, supra note 2, app. C-1

33. See A U niform Sy stem of Citation Rule 26:1 (Columbia Law R eview A ss'n et al. eds., 11th ed. 1967) [hereinafter BLUEBOOK ELEVEN] ("Cited authority supports a statement, opinion, or conclusion of law different from that in text but sufficiently analogous to lend some support to the text."); see also D ickerson, supra note 2, app. C-1 at 216. 
explained." ${ }^{34}$ The fifteenth edition then added a sentence that remains in the present sixteenth edition: "Parenthetical explanations, however brief, are therefore strongly recommended." 35

When the editors of The Bluebook modified the definition and usage of the cf. signal six times in thirty-nine years, ${ }^{36}$ they may have inadvertently changed the common law as well. ${ }^{37}$ Current judges apply contemporary signal definitions in construing older cases that employ signals whose definitions have changed, undoubtedly leading to confusion. This possibility is deeply disturbing because introductory signals arise out of the necessity of citing authority under the rule of law, as well as under The Bluebook. ${ }^{38}$ D espite developments in legal criticism, ${ }^{39}$ the precept that similar situations should receive similar judicial treatment retains obvious appeal. ${ }^{40}$ Such treatment-the rule of law-is integral to the long-standing judicial doctrine of stare decisis, which obligates judges to follow prior decisions. Thus, a modern system of citation ought to insulate writers from accidental misinterpretation of citations and inoculate judges from accidental departures from previous judgments.

$M$ oreover, despite the exhortation of the most recent version of The Bluebook, ${ }^{41}$ cf. citations still go largely unexplained. M any courts

34. A Uniform Sy Stem of CitA tion Rule 2.2(a) (Columbia Law Review A ss'n et al. eds., 13th ed. 1981)

35. Bluebook Fifteen, supra note 19, Rule 1.2(a); Bluebook SiXteen, supra note 3, Rule 1.2(a) (citation omitted).

36. See supra notes 29-35 and accompanying text; see also J.C. Penney Cas. Ins. Co. v. M.K., 804 P.2d 689, 697 n.12 (Cal. 1991) (en banc) (recognizing that the definition of the see also signal had changed between the twelfth and fourteenth editions of The Bluebook).

37. See Dickerson, supra note 2, at 69 ("A uthors use signals to indicate the purpose for which an authority is cited and the weight with which an authority supports or contradicts a particular proposition. Changing what the signals mean effectively changes the substance of our common law." (citation omitted) (citing B owler, supra note 2, at 701 (arguing that even subtle changes in the definitions of signals result in "signals in one generation of law reviews denot[ing] a set of significations that could be inconsistent with the usages known to a later generation"))).

38. See supra notes 3-5 and accompanying text.

39. See generally $\mathrm{G}$ ary $\mathrm{M}$ inda, $\mathrm{O}$ ne $\mathrm{H}$ undred $\mathrm{Y}$ ears of $\mathrm{M}$ odern L egal Thought: From L angdell and Holmes to Posner and Schlag, 28 IND. L. REV. 353 (1995) (reviewing the methods and dominant themes of modern legal thought).

40. See RugGeRO J. A LDISERT, OPINION WRITING § 9.2.8, at 132 (1990) (emphasizing the need for consistency in judicial opinions). This precept has also been described as the governing principle of analogical reasoning. See Karl-Henz Ladeur, The A nalogy Between L ogic and Dialogic of L aw, in LEGAL K NOWLEDGE AND A NA LOGY 12, 18 (Patrick Nerhot ed., 1991).

41. See Bluebook Sixteen, supra note 3, Rule 1.2(a); supra text accompanying note 35 (quoting the fifteenth and sixteenth editions of The Bluebook). 
and legal writers fail to explain the purpose of their cf. citations. Thus, the reader-if he or she thinks about it at all-is left to wonder why the writer employed the cf. signal. Why was the cited primary or secondary authority viewed as positive support for the main proposition? Why was it viewed as less-than-direct support? Precisely how is the cited authority different from the main proposition? In short, what is the nexus between the authority and the proposition? $U$ nless that connection is made clear, the judge or law clerk who later builds on or extrapolates from that elusive citation may move the law in unanticipated or unintended directions. This problem becomes especially acute as judicial caseloads and the corresponding number of published opinions continue to grow. ${ }^{42}$ The resulting pressure to decide more cases more quickly and to justify their rationales in writing has the capacity to lessen the precision of citations and citation practice.

\section{B. Cf.'s Semiotic Function}

From one perspective, this inquiry into the proper role of the cf. signal and its practice epitomizes the elevation of quarrels about the form of legal discourse over those concerning its substance. On the other hand, few would contend that analogical thinking is not essential to the development of law. If the function of the cf. signal relates to analogical reasoning, then the use of the signal must be accepted as an integral, organic part of legal discourse. ${ }^{43}$ This relationship may be conveyed in terms of semiotics, the study of systems of symbols and signs that have communicative value.

Semiotics, broadly defined as "the study of theories of meaning, ${ }^{\prime 4}$ attempts to explain signals' meanings by identifying the role that they play as "signs" in legal discourse. A ccording to

42. See ALDISERT, supra note $40, \S 1.2$, at $1-2$ (noting that the number of judicial opinions submitted for publication has more than doubled in the past thirty years).

43. See Balkin \& L evinson, supra note 2 , at 843 (arguing that the study of legal citation "provide[s] entryways into people's lives and the larger culture in which they live and by which they are shaped").

44. Reed Dickerson, Toward a Legal Dialectic, 61 IND. L.J. 315, 320 (1986). When applied to the legal sphere, for example, structural semiotics demonstrates the dangerous (at least from a pedagogical perspective) circularity of defining rights and duties in relation to one another. "We might imagine, for example, a lawyer simultaneously arguing that a property owner has the right to exclude an unauthorized entrant as a trespasser and that a person seeking unauthorized access to privately held land is a trespasser because the property owner has a right to exclude others." J eremy Paul, The Politics of L egal Semiotics, 69 TEX. L. Rev. 1779,1786 (1991) 
semiologists, signs are shared concepts in the form of words that take their meanings (in part) from the language system in which they operate, and together create culture. ${ }^{45}$ J udicial opinions, for example, are signs; they draw upon facts and authorities to create rules that redefine the circumstances in which the rule will be applied. ${ }^{46} \mathrm{~L}$ egal terms are signs as well; for example, when attorneys or students discuss the tort doctrine of res ipsa loquitur, that term represents a concept or sign understood throughout the legal community. ${ }^{47} \mathrm{~B}$ ut the parameters of semiotics do not end there. A s Professor J ack Balkin writes, "[t]he legal semiotician seeks to identify what might be called the 'grammar' of legal discourse-the acceptable moves available in the language game of legal discourse. These may occur at the level of permissible argument forms, modes of factual characterization, categories of social perception, or in many other ways." ${ }^{48}$ Perhaps the

45. See Roberta Kevelson, The Law as a Sy stem of Signs 4 (1988) [hereinafter KEVELSON, SY STEM OF SIGNS]; Paul, supra note 44, at 1798. A ccording to R oberta K evelson, the foremost legal commentator on the semiotic theory of Charles S. Peirce, semiotics assumes that:

1. A II communication is a process of exchange of meaningful signs, and signs and sign systems such as natural language mediate between communicating persons and those objects in the phenomenal, physical world of experience to which they refer.

2. All human societies have developed complex systems of both verbal and nonverbal sign systems which are not static but which evolve continuously to correspond with and to represent changing social norms and the evolving, growing social consciousness of any given community.

KEVELSON, supra, at 4 (commenting on Charles S. Peirce's theory). "To these major underlying assumptions I would add a third, namely, that ... the entire notion of a legal system, consisting of interrelating communicative processes between legal discourse and legal practice, functions almost universally as a model of dialogic thought development." Id.

It is beyond the scope of this A rticle to explore the possible variances of semiotic theory as they relate to legal citation. Peirce's second assumption, above, concurs with semiologist Ferdinand de Saussure's belief that signs are defined by their interaction in a system of signification such as language. See J.M. Balkin, The Hohfeldian Approach to $L$ aw and Semiotics, 44 U . M IA M I L. REV . 1119, 1121 (1990) (explaining the basic concepts of Continental semiology).

46. See R oberta Kevelson, Semiotics and M ethods of L egal Inquiry: Interpretation and Discovery in $L$ aw from the Perspective of Peirce's Speculative Rhetoric, 61 IND. L.J. 355, 355 (1986) ("[A ]s defined by Peirce, a judgment is a value-sign which acts to bring about an end or goal which, ultimately, has effectual bearing on practical affairs in society.").

47. SeeRoberta Kevelson, Charles S. PeirCe's Method of Methods 1 (1987).

48. J.M. Balkin, The Promise of Legal Semiotics, 69 TEX. L. REV. 1831, 1845 (1991) [hereinafter Balkin, Promise] (footnote omitted). J udge Patricia Wald has expressed the view that judges perform a function related to semiotic inquiry: " $O$ ne needs a sense of context in order to get meaning out of words, in statutes as in life. . . I ordinarily do not dabble in semiotics. I am not a deconstructionist. R ather, I am a judge." Patricia M. Wald, The Sizzling Sleeper: The U se of L egislative H istory in Construing Statutes in the 1988-89 Term of the U nited States Supreme Court, 39 A M . U . L. R E V . 277, 301 (1990). 
most basic move available in legal discourse is the use of introductory signals to evaluate and characterize authority. Signals such as cf. are signs, too-microscopic transmitters of information within the legal community. ${ }^{49}$

Following certain conventions- which, for the purpose of this inquiry into legal citation, may be summarized as "citation practice" - semioticians organize signs into meaningful systems known as codes. ${ }^{50}$ Discovering or interpreting the "preferred meaning" of cf. as a signifier requires review of these codes.

A the outset, one might question whether ascertaining the $\mathrm{cf}$. signal's firm, "preferred meaning" actually benefits the legal system. A Ithough the rule of law should theoretically remain constant, in actuality particular laws frequently change, demonstrating that signs are malleable. "Law . . . may be many things, but it is not a static, determinate, or self-contained system for deriving predetermined, absolute, 'correct' answers to difficult questions." ${ }^{51}$ Introductory signals aid this transformation as law is characterized, applied, and later recharacterized through citation..$^{2}$ Indeed, the meaning of contested political and social signs such as "federalism," "feminism," or "states' rights" can and arguably should drift:

[I]f the rules for interpretation and discovery are said to be a part of any given system of law which they govern, then it must be conceded that the system of law, as a whole, is unstable and that this instability is desirable. What should be apparent here is that legal reasoning, from the realists' point of view, if it is faithful to its pragmatic

49. See Balkin \& Levinson, supra note 2, at 845 ("[C]itation practices are a sort of economy of communication....").

50. See Daniel Chandler, Semiotics for Beginners: Codes (visited Dec. 8, 1998) $<$ http://www.aber.ac.uk/ dgc/sem08.html> (explaining that semiotics "remind[s] us that we are always dealing with signs, not with an unmediated objective reality").

51. Robin Paul Malloy, A Sign of the Times-L aw and Semiotics, 65 TUL. L. REV. 211, 215 (1990) (reviewing K EVELSON, SY STEM OF SIGNS, supra note 45); see also Balkin, Promise, supra note 48 , at 1833 ("[S]igns ... must be capable of iteration and reiteration in a diverse set of new moral, legal, and political contexts.").

52. See, e.g., Balkin, Promise, supra note 48 , at $1833 \&$ nn.10-11 (stating that "the first J ustice Harlan's view that '[0]ur Constitution is color-blind,' had a progressive (and even radical) force in 1896 that becomes completely transformed by 1989, when it is offered by Justice A ntonin Scalia as a justification for the unconstitutionality of affirmative action programs") (citations omitted).

53. See discussion infra notes 57-58 and accompanying text. Once an author recognizes Bluebook niceties-i.e., understands when meanings can shift-then the author is wellequipped to decide whether contested legal signs should shift. That is, once the "rules" are understood, it is then more justifiable for an author to deviate from them. 
ground, must violate the traditional laws of contradiction, that is, a legal system in the process of B ecoming rather than one which is at least, ideally, existent and in place. ${ }^{54}$

M ost signs, if they were ships, could float rudderless. The cf. signal, however-as a device of legal discourse-is at present not seaworthy. There is too little agreement concerning its meaning, which negates its value as a sign. ${ }^{55}$

Of course, unexplained cf. citations provide judges with the flexibility to refine and adapt legal doctrines to the exigencies of justice in particular cases. But predictability in the law is integral to individual justice and the legitimacy of our legal system. The smallest moves in the "language game of legal discourse" ${ }^{56}$ should not be the most consequential. The guideposts for legal analogy should not be set in shifting foundational sands.

It is said that "not even the Emperor A ugustus could effectively mandate the meaning of a word." ${ }^{57}$ Nonetheless, some effort should be made to lend clarity to legal discourse where it is possible. A uthors cannot control their words once they are set upon the page or upon a public digital medium, but readers should be able to distinguish concepts that authors wish to leave ambiguous from those that represent considered thought. With this goal in mind, this A rticle turns to review judicial interpretation of the cf. signal, in order to advance a pragmatic recommendation ${ }^{58}$ to reform the rules of citation.

\section{Kevelson, supra note 46 , at 362 .}

55. SeeKEVELSON, supra note 47, at 5-6.

That the meaning of a sign is based on the mutual agreement between users of the sign is one of Peirce's major assumptions. Signs designate aspects of the real world through contractual action.... Thus to speak of a fact is to speak of a community of qualitative likenesses and differences....

Id. On the other hand, cf.'s ambiguity may heighten readers' skepticism regarding the use of the signal to revise or even ignore authorities, which ultimately serves the semiotic goal of exposing ideologies, "mak[ing] us aware of what we take for granted in representing the world." D aniel Chandler, Semiotics for B eginners: Strengths of Semiotic A nalysis (visited D ec. 8, 1998) <http://www.aber.ac.uk/ dgc/sem10.html>.

56. B alkin, Promise, supra note 48, at 1845.

57. Dickerson, supra note 44 , at 324 .

58. Considerable disagreement surrounds the question of whether semiotics is a prescriptive or merely descriptive field. On one side of the controversy, it is argued that "legal semiotics is useful because it will allow us to clarify hidden tensions in the law and assist us in the continuing refinement of our moral and legal intuitions." B alkin, Promise, supra note 48, at 1836; see also Paul, supra note 44 , at $1807 \&$ n.76. D uncan Kennedy's work in constructing categories of legal argumentation has been described as legal semiotics because he "emphasized the ways in which legal concepts draw meaning from their place within broader 


\section{The Cf. Signal in Published Opinions}

When courts use the cf. signal, legal discourse often goes up in smoke. A review of recent citation practice in published opinions ${ }^{59}$ reveals that, like their counterparts before the bar, the legal writers on the bench use and interpret cf. citations in an unpredictable, inconsistent, and occasionally outright contradictory fashion. Part of the reason, no doubt, is that law clerks typically draft initial opinions and judges review those drafts. But judges do not often pick over draft opinions to check marginal signals. Thus, a sloppy signal system permits law clerks to make (or unmake) law in ways that we do not even notice. This Part explains the creative dilemma posed by the cf. signal, reviews the spectrum of meanings that legal writers have ascribed to the signal, and illustrates the cf.'s hidden communicative possibilities.

\section{A. A nalogical Reasoning with "Cipher" Signals}

Strangely, although analogical thinking is highly valued as a skill in the practice of law, the word "analogy" often appears in the case reports alongside "inapposite," "speculative," and other pejorative words and phrases from the legal lexicon. ${ }^{60}$ In no place is this disapprobation more apparent than in judicial decisions construing the cf. signal. In State v. Stafford, ${ }^{61}$ for example, the North Carolina Supreme Court appeared to draw a stark line between authority and analogical reason by dismissing a petitioner's citation as improvidently based on a double jeopardy case that did "not bear upon the matter of punishment, ${ }^{62}$ with the following statement:

legal argument, just as semioticians have stressed the ways in which words take meaning from their place within a larger linguistic system." Id. at 1781-82. On the other side of the debate, $R$ oberta K evelson excludes such structuralist approaches from the realm of Peircian semiotics. See K evelson, supra note 46, at 357.

59. The case reports contain countless examples of cf. signal usage, but this A rticle cannot hope to encompass even a moderate portion of this citation practice. Instead, this review winnows the bulk of 'signal' decisions to those that use or analyze the cf. signal, its ambiguity, or its potential to mislead.

60. See, e.g., D enver A rea E duc. Telecomms. Consortium, Inc. v. FCC, 518 U .S. 727, 738 (1996); Stinson v. U nited States, 508 U .S. 36, 44 (1993); R .A .V . v. City of St. Paul, 505 U .S. 377, 418-19 (1992); General Elec. Co. v. Rees, 217 F.2d 595, 598 (9th Cir. 1954); State v. R osencrantz, 714 P.2d 93, 99 (I daho A pp. 1986).

61. 164 S.E.2d 371 (N.C. 1968).

62. Id. at 376. (citing Green v. U nited States, 355 U.S. 184 (1957)); see also infra Part II.B (discussing the entire category of similar judicial treatment). 
For [the cited court's] statement that 'there must be repose not merely as to the severity of the court's view, but as to the severity of the crime,' it cited no authority but suggested by way of a 'cf.' that Green v. U nited States was sufficiently analogous to lend some support to its statement. ${ }^{63}$

The translation of arguably dissimilar principles and facts into new circumstances seems integral to the production of law, but it apparently ceases to influence some courts when preceded by the cf. signal, becoming mere analogy. ${ }^{64}$ Perhaps analogical reasoning elicits such disapproval because judges must spend their days employing it. ${ }^{65}$

63. Stafford, 164 S.E.2d at 376 (emphasis added) (citation omitted). A lthough not cited in the opinion, the language appears to track that of The Bluebook. See, e.g., BLUEBOoK ELEVEN, supra note 33, R ule 1.2(a) (containing identical language ("sufficiently analogous to lend some support to its statement") to that of the court); BLUEBOOK SIXTEEN, supra note 3, R ule 1.2(a) (same except for the deletion of the word "some").

64. A t least two cases demonstrate the persistence of the distinction between analogical and controlling authority. See Local 194, R etail, Wholesale \& D ep't Store U nion v. Standard B rands, Inc., 540 F.2d 864, 867 (7th Cir. 1976) (holding that the union had standing to bring a Title VII action despite Warth v. Seldin, 422 U.S. 490 (1975), because W arth's cf. citation to Federal R ule of Civil Procedure 23 suggested that the Federal R ule's class-action requirements were "applicable only by analogy"); U nited States v. Carter, 522 F.2d 666, 685 n.62 (D.C. Cir. 1975) ("The court upheld the introduction ... and referred to [the statute] with a 'cf.' citation, indicating the reference was by analogy and not a direct holding under the statute." (citing U nited States v. A ngelo, 153 F.2d 247 (3d Cir. 1946))).

65. For example, the Supreme Court's use of the cf. citation as analogical support in Patterson V. MCL ean Credit Union, 491 U.S. 164, 185 (1989) (responding to a racial discrimination suit by ruling that an employer violated $\S 1981$ of the Civil R ights A ct only if the promotion would have resulted in a "new and distinct relation between the employee and the employer"), has received criticism. The Patterson Court followed this statement with a cf. citation to Hishon v. King \& Spaulding, 467 U.S. 69 (1984), in which a law firm associate challenged her failure to be invited into the partnership on Title VII grounds. See Patterson, 491 U .S. at 185. The J ustices inferred in Patterson that the Court's intention in $\mathrm{H}$ ishon was to provide at least an example of what situation would constitute the required new relationship. See id. at 186. H owever, as the Sixth Circuit subsequently noted in H olt v. M ichigan D ep't of Corrections, 974 F.2d 771 (6th Cir. 1992), "some courts have viewed H ishon's facts to fall somewhere in the middle of a continuum of employment scenarios that give rise to 'new and distinct' employment relations." I d. at 774 (discussing Patterson, 491 U .S. at 185).

Judges who consider $\mathrm{cf}$. citations rarely get to reproach counsel who construct improper analogies, although such improper use can be devastating. But see Wolgin v. Magic Marker Corp., 82 F.R.D. 168 (E.D. Pa. 1979). In this securities fraud action, the plaintiff's motion for class-action certification was at issue. The defendant argued that Federal Rule of Civil Procedure 23(a)(4)-which requires that "the representatives will fairly and adequately protect the interests of the class" - was not satisfied by the class, but the court vigorously rejected that contention:

Defendant's vehement opposition to this motion for class action certification has apparently led defense counsel to take certain liberties with the precedents upon which they rely. I was particularly surprised to see my own opinion in Axelrod $v$. Saks \& Co., 77 F.R.D. 441 (E.D. Pa. 1978)-an opinion in which I found no conflicts of interest among the named plaintiffs and the class members, and so unhesitantly 
The result of this intensely creative enterprise is that, as often as not, cf. analogies are misunderstood. If the author of the citation has a later opportunity to explain, ${ }^{66}$ then the original analogy might be recovered, but only after considerable confusion or a proliferation of unintended consequences.

E arnest judges wander in literally every direction seeking the elusive meaning of cryptic cf. citations. In the bulk of cases, courts follow the definitions set out in successive editions of The B luebook ${ }^{67}$ and attempt to construct analogies that represent positive authority for the proposition offered. ${ }^{68}$ In some situations, however, courts use the cf. to construct analogies that damage the suggested conclusion, failing to recognize the original author's motivation as well as the substance of his or her analogy. Some courts essentially ignore relevant $\operatorname{cases}^{69}$ or dismiss precedent introduced by the cf. signal as

certified the proposed class-cited by defendants here in support of this proposition:

"Numerous courts have viewed the presence of even a potential conflict as a ground

for summary denial of class certification."

Id. at 174 n.1. The defendant's citation of Axelrod was preceded by a cf. signal. The judge continued: "One can only wonder what proposition 'sufficiently analogous' to the quoted proposition derives support from A xelrod." Id.

66. The author could, of course, explain the citation in a parenthetical. For a further discussion of the need for parenthetical explanation when using the cf. citation, see infra Part III.B.

67. See, e.g., Stafford, 164 S.E.2d at 376 (tracking in 1968 The Bluebook's definition of the cf. signal from the 1967 edition of The Bluebook (BLUEBOOK ELEVEN, supra note 33)).

68. See supra notes 29-35 and accompanying text (summarizing past and present definitions of signal). While Bluebook definitions of the cf. signal have shifted over time, the common rationale underlying each change is the recognition that the cited authority, while reliant upon different facts, at least supports the stated proposition.

69. See, e.g., U nited States v. Ridinger, 623 F. Supp. 1386, 1397 (W.D. M o. 1985) (criticizing the First Circuit for ignoring relevant precedent in United States v. A cevedo-Ramos, 755 F.2d 203 (1st Cir. 1985)). In Ridinger, the district court considered an appeal from a magistrate judge's detention order. See Ridinger, $623 \mathrm{~F}$. Supp. at 1388. The magistrate judge's finding included a declaration that the defendant had been involved in two murders, evidence of which was considered in camera and was not provided to either the government's attorneys or the defendant and his attorney. See id. at 1389. The magistrate judge stated that A cevedoRamos supported his in camera review. See id. at 1397. A cevedo-Ramos held that a magistrate could examine evidence in camera in a bail hearing where the government could show a necessity for keeping sources confidential. See A cevedo-Ramos, 755 F.2d at 208-09. The Ridinger court, however, stated: "[W ]e believe that the First Circuit looked the other way when it decided that case." Ridinger, 623 F. Supp. at 1397. In support of that statement, the court pointed to two cf. cites in A cevedo-Ramos to U nited States v. Stanford, 551 F. Supp. 209 (D. M d. 1982). See Ridinger, 623 F. Supp. at 1398. In A cevedo-Ramos, the judge heard testimony from an $\mathrm{FBI}$ agent based on hearsay from confidential sources and the defense attorneys were able to cross-examine that agent. See A cevedo-Ramos, 755 F.2d at 205. The A cevedo-Ramos court cited Stanford for the proposition that the judge can test the accuracy of evidence and testimony by considering information in camera. See id. at 208. In fact, Stanford merely held that, as the defendant was provided with a summary of the sealed affidavit, he did have an 
"distinguishable"-despite the fact that The Bluebook identifies authorities so introduced as supportive authority ${ }^{70}$-and go on to perform novel analyses. In Toledo TV Cable Co. v. Commissioner, ${ }^{71}$ for example, the U nited States Tax Court glossed over its previous endorsement of an authority by stating, "our citation was preceded by the signal 'cf.' which hardly connotes approval." ${ }^{72}$

When the nation's highest court fails to explain cryptic cf. citations, the clarity and predictability of A merican law suffers profoundly. The best example of the Supreme Court's use of an ambiguous of. citation is Stone v. Powell, ${ }^{73}$ a case that many lower federal courts $^{74}$ and commentators ${ }^{75}$ have analyzed extensively. Perhaps the Court deliberately utilized a cf. citation in order to avoid having to define its terms, to provide needed flexibility to lower court decisionmakers, or to avoid expansion of the Fourth A mendment. ${ }^{76}$ It is impossible to know. The result has been time-consuming construction, deconstruction, and extrapolation of reinventive analogies. The Stone Court limited the relief available to prisoners asserting Fourth A mendment violations on collateral review of their

opportunity to refute the evidence and his due process rights were not violated. See Stanford, $551 \mathrm{~F}$. Supp. at 211.

70. See Bluebook Sixteen, supra note 3, R ule 1.2(a).

71. 55 T.C. 1107 (1971).

72. Id. at 1120. The issue before the court was whether certain municipal franchises for cable television have determinable useful lives. The petitioner relied on Birmingham $\mathrm{N}$ ews $\mathrm{Co}$. v. Patterson, 224 F. Supp. 670 (N .D . A la. 1963), to show that a contract that is "subject to some substantial renegotiation after the term of the contract has a determinable useful life." Toledo TV , 55 T.C. at 1119 (internal quotation marks omitted). The petitioner argued further that the Toledo TV court had previously agreed with that proposition in David Hoffman $\mathrm{V}$. Commissioner, 48 T.C. 176 (1967). See Toledo TV, 55 T.C. at 1120. The Toledo court rejected the suggested endorsement with the language quoted above. See id.

73. 428 U.S. 465 (1976).

74. See infra notes $80-87$.

75. See, e.g., Sam B oyte, Federal Habeas Corpus A fter Stone v. Powell: A Remedy O nly for the A rguably Innocent?, 11 U . R ICH . L . REV . 291 (1977); R obert M . Cover \& T. A lexander A leinikoff, Dialectical Federalism: Habeas Corpus and the Court, 86 Y A LE L.J. 1035 (1977); Philip $\mathrm{H}$ alpern, Federal $\mathrm{H}$ abeas Corpus and the M app Exclusionary Rule A fter Stone v. Powell, 82 Colum. L. Rev. 1 (1982); Ira P. Robbins \& James E. Sanders, Judicial Integrity, the A ppearance of J ustice, and the $\mathrm{G}$ reat W rit of $\mathrm{H}$ abeas Corpus: $\mathrm{H}$ ow to K ill Two Thirds (or M ore) with $O$ ne Stone, 15 A M. CRIM. L. Rev. 63 (1977); Peter McCormack, Comment, H abeas Corpus and Due Process: Stone v. Powell Restricted, 17 Hous. L. REV. 923 (1980); James Turner, Comment, Habeas Corpus A fter Stone v. Powell: The "O pportunity for Full and Fair L itigation" Standard, 13 H A RV. C.R .-C.L. L. REV. 521 (1978).

76. See Larry W. YackLe, Postconviction Remedies § 99 (1981 \& Supp. 1998) (summarizing the views of courts and commentators); see also IRA P. ROBBINS, HABEAS CORPUS CHECKLISTS Ch. 7 (1999) (discussing Stone and its progeny). 
convictions. It stated: "[W]here the State has provided an opportunity for full and fair litigation of a Fourth A mendment claim, a state prisoner may not be granted federal habeas corpus relief on the ground that evidence obtained in an unconstitutional search or seizure was introduced at his trial." ${ }^{17}$ Footnote thirty-six, which followed this assertion, ${ }^{78}$ contained only a cf. citation to the entire case of Townsend $v$. Sain. ${ }^{79}$ The Court thus failed to clarify the significance of the Townsend opinion to Stone. Nor did the concurring opinion or either of the two dissenting opinions include any discussion of the inscrutable reference to Townsend.

The lower federal courts have sought to make sense of the citation, variously interpreting Townsend through the prism of Stone to discern the following: what Stone's footnote thirty-six does not mean; ${ }^{80}$ what clues Stone and Townsend provide; ${ }^{81}$ whether the

77. Stone, 428 U .S. at 494 (footnote omitted).

78. See id.

79. 372 U .S. 293 (1963). Townsend involved a defendant petitioning for habeas corpus relief because his confession, which was admitted into evidence at trial, had been procured through the use of a truth serum. The Court ruled that the standard for when a habeas court should grant an evidentiary hearing to a petitioner is where facts are in dispute and the defendant "did not receive a full and fair evidentiary hearing" at trial. Id. at 312. The opinion listed six circumstances in which a federal court must grant an evidentiary hearing. See id. at 313. It is most likely that this is the discussion in Townsend to which the Stone Court referred.

80. See G ates v. H enderson, 568 F.2d 830, 836-40 (2d Cir. 1977) (en banc) (finding that the defendant had the opportunity to fully and fairly litigate his claim, but failed to raise it). The $\mathrm{G}$ ates court concluded that Stone and Townsend did not completely define the "full and fair hearing" required by the Fourth A mendment:

While we are not fully appreciative of the significance of the footnoted reference, we are persuaded that it cannot be reasonably interpreted to require a federal court to conduct a hearing on an issue where the state prisoner, having an opportunity to do so, never tendered the question to the state court. Such a proposition would totally undercut the thrust and rationale of Stone.

Id. at 838. The concurring opinion in $\mathrm{G}$ ates similarly speculated that Stone established a very general standard under which the courts could examine each case based on its particular facts without deferring to the Townsend criteria. See id. at 840-44 ( 0 akes, J., concurring).

81. See O'Berry v. Wainwright, 546 F.2d 1204 (5th Cir. 1977). In O'Berry, the Fifth Circuit disagreed with a petitioner who claimed that Townsend defined what the Stone Court meant by an "opportunity for full and fair litigation" of a Fourth A mendment claim. The court stated: " $[A]$ lthough we agree that Townsend is of some help in defining 'full and fair adjudication' by a state court, we cannot ... . endorse its wholesale use" in considering whether to hear petitioner's claim. Id. at 1211. A ccording to the Fifth Circuit, Townsend "applies only in determining whether a state court has granted Petitioner a full and fair evidentiary hearing-a hearing limited to findings of fact." Id. The majority concluded that $\mathrm{O}^{\prime} \mathrm{B}$ erry involved only legal issues, stripping the Townsend test of most of its usefulness. See id. The Fifth Circuit also examined the cf. citation in deciding whether "full and fair" consideration requires hearings in state trial courts as well as appellate courts, but shed little light on the controversy: "[Consistent] with the ambiguity of the Supreme Court's opinion, ... sometimes 'full and fair 
Townsend test can be "applied literally" ${ }^{82}$ or not; ${ }^{83}$ whether the Stone Court intended to "engraft" the Townsend criteria into its holding; ${ }^{84}$ whether Stone made a "backhanded reference" to Townsend, ${ }^{85}$ so that the Townsend test "must be filtered through the holding and rationale of Stone before it can be applied to state court fourth amendment proceedings"; ${ }^{86}$ and whether the Court would have been so subtle as to premise its analysis on a case cited with a cf. signal in a footnote. ${ }^{87}$

consideration' means consideration by two tiers of state courts-sometimes it requires consideration by only one." Id. at 1213.

82. Mack v. Cupp, 564 F.2d 898, 901 (9th Cir. 1977). "In Stone, the Court cited as analogous authority Townsend $v$. Sain, which established criteria for determining when a federal district court should hold an evidentiary hearing in a habeas corpus proceeding." Id. at 900 (citation omitted). "A Ithough . . . the Townsend test must be given great weight in defining what constitutes full and fair consideration under Stone, we do not believe that it must always be applied literally ...." Id. at 901. The N inth Circuit concluded that Townsend's contemplated use of state fact-finding procedures in Fourth Amendment claims exceeded Stone's requirement that the state extend an opportunity for "full and fair" deliberation. See id.

83. See D unn v. R ose, 504 F. Supp. 1333, 1337-38 (M.D. Tenn. 1981) ("Stone seems to contemplate that, when the facts of a search-and-seizure claim are in dispute, 'fullness and fairness' require a state court hearing that satisfies the criteria of Townsend v. Sain." (citation omitted)). In the eyes of at least one judge, the reference to Townsend was "the only substantive indication of what the Supreme Court meant by an opportunity for full and fair litigation." Id. at 1338. He concluded that petitioners raising Fourth A mendment claims would be "entitled to a federal evidentiary hearing if the state court proceedings failed to pass muster under the Townsend criteria." Id. The judge observed, however, that the cf. signal intimated that the Townsend criteria were not to be applied literally: "To the extent that Townsend [would] require[] a reweighing of the merits (e.g., determining whether the record 'fairly supports' the state courts' decision), its application would be inconsistent with the res judicata principle underlying Stone." Id.

84. Doleman v. M uncy, 579 F.2d 1258, 1264 (4th Cir. 1978). The court acknowledged both the petitioner's argument along such lines and the state's demurral that, "[h]ad the Court intended to engraft the Townsend v. Sain criteria into the Stone situation, it could have done so expressly instead of by a passing footnote reference." Id. U Itimately finding that, although Stone required an investigation into whether there was an opportunity to raise the Fourth A mendment claims, the court stated that the Townsend inquiry only becomes an issue if, after the question of opportunity has been satisfied, the prisoner alleges "something to indicate that his opportunity for a full and fair litigation of his Fourth A mendment claim . . . was in some way impaired." Id.

85. Palmigiano v. H oule, 618 F.2d 877, 881 (1st Cir. 1980).

86. Id. In Palmigiano, the court addressed the issue of whether the "misallocation of the burden of proof denied petitioner a full and fair opportunity to litigate his fourth amendment claims." Id. The court held that "the criteria set forth in Townsend can be used as a guide in determining whether there has been full and fair state litigation of fourth amendment claims, [but] they are not commandments the breaking of any of which absolutely requires an evidentiary hearing in the federal court." Id. at 882.

87. See Willett v. Lockhart, 37 F.3d 1265, 1267-69 (8th Cir. 1994) (noting that Stone's confusing cf. citation had led to “lower federal courts' applying a degree of habeas review that 
Predictability of the law suffers because an author can no longer control how the reader perceives an idea once it is committed to paper. U nexplained cf. citations such as Stone's notorious footnote thirty-six exacerbate this problem and drain judicial resources on a significant scale because authors so often fail clearly to express their ideas in words, forcing the reader into an exhausting search for meaning. Some of the time-consuming analogical constructions done by the lower courts in the aftermath of Stone could have been avoided if the Court had seen fit to reference Townsend with a parenthetical phrase-as The Bluebook now strongly recommends for all citations beginning with cf.- explaining why it cited Townsend, or even provided a pinpoint citation identifying the part of the decision that it wanted the reader interpreting Stone to apply. Instead, unexplained cf. usages like this force diligent judges to wander in search of-and wonder about-the meaning of these cryptic citations. The following subsections illustrate the spectrum of interpretations applied to ambiguous cf. citations in a host of lower court decisions.

1. Positive or Persuasive A uthority. A Ithough cf. citations are sometimes considered marginal or makeweight support for legal propositions, ${ }^{88}$ courts frequently interpret authorities preceded by the cf. signal as positive, contributory grounds for their conclusions. ${ }^{89}$ For

ranges from imperceptible to quite broad," and concluding that "[t]he cf. signal tells us that Townsend supports a different proposition" from that of Stone).

88. See State v. M cK inney, 917 P.2d 1214, 1235 (A riz. 1996) (M artone, J., dissenting) ("The use of the cf. cite is a frank acknowledgment that there is no clear support for the proposition."); see also Hensley v. Eckerhart, 461 U.S. 424, $433 \&$ n.8 (1983). H ensley cited several cases for the proposition that a "prevailing party" for purposes of recovering attorney's fees under 42 U.S.C. § 1988 (1982) is one who "succeed[s] on any significant issue." Id. The Court then used a cf. signal, in a footnote, to refer to a case requiring "success[] on the central issue," and failed to resolve the apparent conflict between these two propositions. Id.; see also Fast v. School Dist., 728 F.2d 1030, 1032 n.2 (8th Cir. 1984) (stating that the Supreme Court's description of a legal rule as "a typical formulation" did not suggest any disagreement, and that the only alternative rule "appears in a footnote as a parenthetical description of a holding by another circuit, preceded by the signal ' $\mathrm{Cf}$.'").

89. See, e.g., Chemical Bank v. A rthur A ndersen \& Co., 726 F.2d 930 (2d Cir. 1984). In this case, the Second $C$ ircuit considered whether unsecured replacement notes evidencing loans made by a bank were securities within the meaning of the Securities Exchange Act and the Securities and Exchange Commission's rules. It quoted language from the Supreme Court's decision in M arine B ank v. Weaver, 455 U .S. 551 (1982):

The [M arine] Court cited [with a cf. signal] Judge Wright's concurring opinion in G reat Western Bank \& Trust [v. K otz, 532 F.2d 1252 (9th Cir. 1976),] in footnote 10 as supporting authority for its holding that the "agreement, negotiated one-on-one by 
example, Justice Blackmun's dissent in Florida v. Riley ${ }^{90}$ correctly recognized that the cf. signal connotes supporting, though not controlling, authority. He wrote, "[t]he opinions of both Justice Brennan and Justice O'Connor, by their use of 'cf.' citations, implicitly recognize that none of our prior decisions tells us who has the burden of proving whether Riley's expectation of privacy was reasonable." ${ }^{91}$

E ven among courts that view cf. citations as positive authority, courts assign differing weights to those authorities. In L ebowitz v. Forbes $L$ easing \& Finance Corp. ${ }^{92}$ a federal district court determined that a cf. citation presented controlling authority. L ebowitz involved a challenge to the Pennsylvania foreign attachment procedures that was raised in light of the Supreme Court's decision in Sniadach v. Family Finance Corp., ${ }^{93}$ which struck down W isconsin's prejudgment garnishment procedure because it violated due process. ${ }^{94}$ A fter examining Sniadach and its progeny, the court expressed "grave doubts" about whether the procedures followed in Pennsylvania were constitutional. ${ }^{95}$ But it decided that it was compelled to uphold the procedures based on two citations by the Supreme Court in Sniadach. The first citation, introduced by a cf. signal, identified 0 wnbey $v$. Morgan ${ }^{96}$ as supporting the conclusion that prejudgment attachments may satisfy due process in "extraordinary situations." ${ }^{97}$ Sniadach then used a see signal to cite $M c K$ ay v. $M c l n n e{ }^{98}$ for the proposition that prejudgment attachments may satisfy due process in general if not in every situation. ${ }^{99}$ The L ebowitz court concluded that Sniadach "at least recognizes the vitality of $\mathrm{O}$ wnbey and $\mathrm{M}$ CK ay, even if it does not impliedly approve of them." ${ }^{100}$ Thus, the court concluded that it was

the parties, is not a security." . . . Thus, the Court's reference to Judge W right's concurring opinion must be regarded as an approving one.

Chemical B ank, 726 F.2d at 938 n.14 (quoting M arine B ank, 455 U .S. at 560).

90. 488 U .S. 445 (1989).

91. Id. at 467 (Blackmun, J., dissenting) (addressing the Court's holding that police helicopter surveillance does not infringe on a homeowner's legitimate expectation of privacy).

92. 326 F. Supp. 1335 (E.D. Pa. 1971).

93. 395 U .S. 337 (1969).

94. See id. at 342

95. L ebowit, 326 F. Supp. at 1352.

96. 256 U .S. 94 (1921).

97. Sniadach, 395 U .S. at 339, cited in L ebowitz, 326 F. Supp. at 1352.

98. 279 U .S. 820 (1929) (per curiam).

99. See Sniadach, 395 U .S. at 340, cited in L ebowitz, 326 F. Supp. at 1352.

100. L ebowitz, 326 F. Supp. at 1353. 
bound to uphold the Pennsylvania attachment procedures, even though it evidently felt that the Supreme Court might decide those cases differently if presented with the opportunity.

$\mathrm{G}$ iven the definition of the cf. signal-that it refers to authorities that "lend support" ${ }^{101}$ - cases like Lebowitz are troublesome. If commentators are to ascribe valid meanings to introductory signals and the citations they select, surely using authorities prefaced by the cf. signal as positive authority to the point where it controls or dictates a result increases ambiguity and reduces the clarity of those decisions. Such use of the cf. imperils the quest for uniformity in interpretation and thwarts the goal of achieving predictable outcomes in similar cases.

2. Unclear Authority: Citation Under Weightless Conditions. A nother response to indecipherable cf. citations is to treat them as malleable, oblique allusions to other doctrines or judges. ${ }^{102}$ Clearly there is some value in controlled or intentional ambiguity, which use of the cf. signal masks well. It permits judges to refrain from pronouncing too much law, especially in situations in which they anticipate unpredictable factual situations that may necessitate caseby-case analysis, or when dealing with controversies that implicate broad social disputes unripe for decision. The unexplained cf. citation introduces authority that permits the author to declaim that the opinion contains some statement on an issue, without drawing necessary (or even permissible) conclusions.

101. Bluebook SiXteen, supra note 3, Rule 1.2(a). See Alaska v. Federal Energy R egulatory Comm'n, 980 F.2d 761, 763 (D.C. Cir. 1992) (explaining that an earlier opinion's use of a cf. citation to a Supreme Court case was employed because "[t]he theory underlying both decisions is the same"); Chemical B ank v. A rthur A ndersen \& Co., 726 F.2d 930, 938 n.14 (2d Cir. 1984) (setting forth the still-operative Bluebook definition of cf.- "that the cited authority supports a proposition different from the main proposition but sufficiently analogous to lend support" - and concluding that the Supreme Court's use of a cf. citation "must be regarded as an approving one" (citations omitted)).

102. See Reibor Int'I Ltd. v. Cargo Carriers (KA CZ-CO.) Ltd., 759 F.2d 262 (2d Cir. 1985). In this admiralty case, a vessel owner sought to garnish funds to be remitted to the charterer under a letter of credit as funds were transferred from a Spanish bank to a Canadian bank through New York banks. See id. at 263-64. The court agreed with the appellant's argument that Ratto v. Italia, 12 N.Y.S.2d 617 (City Ct. 1938), was "a fair and equitable decision," but decided that it was a weak precedent because the decision was based on two cf. references. See Reibor Int'I Ltd., 759 F.2d at 267. It concluded that the decision [Ratto] is "hardly likely to be followed by any N ew Y ork court considering facts like those before us." Id; see also supra notes 73-79 and accompanying text (discussing ambiguous cf. reference in Stone v. Powell). 
In G ifford v. Tiernan, ${ }^{103}$ for example, the Ninth Circuit held that the claim of an individual who proceeded in forma pauperis, challenging the constitutionality of the Federal Election Campaign A ct (FECA ) ${ }^{104}$ could be dismissed as frivolous without certification to the court of appeals for expedited en banc review, pursuant to FECA ${ }^{105}$ At issue was the then-recent statement by the Supreme Court in California M edical A ss'n v. Federal Election Commission: ${ }^{106}$ "[W ]e do not construe $\S 437 \mathrm{~h}$ to require certification of constitutional claims that are frivolous . ..." ${ }^{107}$ The $\mathrm{N}$ inth Circuit acknowledged that "[i]t is not entirely clear whether this statement by the Supreme Court refers solely to claims classified as 'frivolous' within the meaning of 28 U .S.C. $\S 1915(d) . "{ }^{108}$ The Supreme Court had followed its statement with an unexplained cf. citation to California Water Service Co. v. City of Redding, ${ }^{109}$ which dealt with dismissals of previously decided federal questions or other claims without merit. The Ninth Circuit, left to its own devices in interpreting the case, plugged the facts of each case into The Bluebook's of. definition, ${ }^{110}$ and concluded that "the Supreme Court considers dismissals as frivolous pursuant to 28 U .S.C. $\S 1915$ (d) to be analogous to, but not identical with, dismissals for lack of a substantial federal question." ${ }^{111}$ W ithout further comment, the $\mathrm{N}$ inth Circuit found other grounds for its decision "that the [Supreme] Court feels that 'insubstantial' questions need not be certified." 112 The Supreme Court's ambiguity, therefore, remained unclarified.

This authorial sleight of hand allows the judiciary to retain its normative function and resolve the present controversy while leaving the scene with few legal fingerprints. Depending on the reader's perspective, such ambiguity might represent an intolerable refusal to acknowledge and discuss patent legal conflicts. E ven if it is desirable

103. 670 F.2d 882 (9th Cir. 1982).

104. Federal Election Campaign A ct of 1971, Pub. L. 92-225, 86 Stat. 11 (1972) (codified as amended at 2 U .S.C. $\S 431(1994)$ ).

105. See G ifford, $670 \mathrm{~F} .2 \mathrm{~d}$ at 883.

106. 453 U.S. 182 (1981).

107. Id. at 193-94 n.14.

108. G ifford, $670 \mathrm{~F} .2 \mathrm{~d}$ at 884 n.6.

109. 304 U .S. 252 (1938) (per curiam).

110. See Gifford, 670 F.2d at 884 n.6 (remarking that "the Supreme Court's footnote follows with a Cf. signal and a citation to [California Water]").

111. Id.

112. Id. 
to eliminate intentional ambiguity, ${ }_{1}^{113}$ however, this situation may be difficult to surmount. If judges are using the cf. signal to identify intentional ambiguities, then proscribing deliberate vagueness may be an inadequate solution because the author may want the issue to be resolved either at a later time or by a different court.

3. Dismissed as Distinguishable. In many cases, courts fail to reconcile seemingly contradictory laws and use the cf. signal as a wildcard, interpreting the cited case with whatever weight or significance they choose. Such behavior abnegates the author's intended meaning with prejudice, because The Bluebook identifies the cf. signal as a supporting signal that may be used when the authority is not directly on point. ${ }^{114}$ The primary mechanism through which these courts interpret of. references is to dismiss or discard the cited authority as distinguishable, either in the facts stated ${ }^{115}$ or occasionally in the legal proposition cited. ${ }^{116}$ Some decisions also

113. Intentional ambiguity is, indeed, the defining attribute of riddles:

The riddle is an arrangement of words by which is understood or suggested something that is not expressed; or else it is an ingenious and witty description of this unexpressed thing by means of qualities and general traits that can be attributed quite as well to other things having no likeness or analogy to the subject.

Charles T. SCott, Persian and A Rabic Riddles: A Language-Centered A pproach TO GENRE DEFINITION 14 (1965) (footnote omitted).

114. See Bluebook Sixteen, supra note 3, Rule 1.2(a).

115. See In re The A merican Tobacco Co., 866 F.2d 552 (2d Cir. 1989). The court dealt with the issue of an appeal taken from two orders to enforce third-party subpoenas against the appellants. See id. at 553. In Dixon v. 80 Pine Street Corp., 516 F.2d 1278 (2d Cir. 1975), the Second Circuit analyzed the lower court's and the merits panel's cf. citation to U nited States v. Nixon, 418 U .S. 683 (1974):

Though the citation to Nixon suggests that the merits panel may have thought that the need for a contempt adjudication was as inappropriate for the City as the Supreme Court thought it was for the President [in Nixon] our Court has subsequently viewed Dixon as something of an aberration from the usual rule against appealability.... Whether $\mathrm{D}$ ixon is to be diminished as resting on a non-precedential order or distinguished because it involved a city and contempt had been sought without success, it does not commit this Circuit to abandonment of [a prior rule], which we have repeatedly acknowledged.

A merican Tobacco, 866 F.2d at 555; see also infra notes 118-27 (discussing Givens v. United States).

116. See Northern Tankers (Cyprus) Ltd. v. Backstrom, 967 F. Supp. 1391, 1401 (D. Conn. 1997) (using a cf. citation to two cases to illustrate the difference between $\mathrm{N} \mathrm{ew} \mathrm{Y}$ ork and federal maritime law). The two appellate cases cited in Northern Tankers had both cited to $\mathrm{N}$ ew Y ork law and then used the cf. signal to reference federal maritime law. See Carte Blanche (Singapore) PTE., Ltd. v. Diners Club Int'I, Inc., 2 F.3d 24, 26 (2d Cir. 1993); W m. Passalacqua Builders, Inc. v. R esnick D evelopers South, Inc., 933 F.2d 131, 138 (2d Cir. 1991). A pparently the cf. signal indicates that the two are parallel, but not identical.

Similarly, in M arzonie v. A uto Club Insurance A ss'n, 495 N.W.2d 788 (M ich. 1992), the Supreme Court of M ichigan criticized the court of appeals' improper use of the cf. signal, see id. 
distinguish and dismiss cited cases based on their general inapplicability or inappropriateness, limited neither to the facts nor to the law cited. ${ }^{117}$

Givens v. United States ${ }^{118}$ provides a nice example in this "dismissed as distinguishable" category. In Givens, the petitioners challenged their convictions because of delays between an original indictment, later dismissed, and their trial on the second indictment. ${ }^{119}$ The issue was whether the Sixth A mendment's guaranty of a speedy trial applied to the time interval between dismissal of the first charge and trial on the second. ${ }^{120}$ The Givens court considered two prior cases involving the same issue- $B$ ranch $v$. U nited States ${ }^{121}$ and Robinson v. U nited States. ${ }^{122}$ In B ranch, the court held that the time interval between dismissal of a first indictment and the filing of a second was relevant to Sixth A mendment analysis. ${ }^{123}$ In Robinson, the court held that the same period did not apply to the right to a speedy trial, ${ }^{124}$ following a similar rule announced in a recent Supreme Court case, U nited States v. MacD onald. ${ }^{125}$ The Robinson court cited B ranch with a but cf. signal, "but did not suggest any distinction that would allow the earlier decision to survive the

at 792 n.4, in the course of reversing the lower court's ruling that an insured automobile driver was entitled to personal insurance benefits for gunshot wounds sustained while occupying his car, see id. at 793. R elying on Thornton v. Allstate Insurance Co., 391 N.W .2d 320 (M ich. 1986), the court denied benefits to the driver because the car was not the instrumentality of his injuries. See M arzonie, 495 N.W .2d at 793. In Thornton, however, the M ichigan Supreme Court had confronted similar facts in which "the injury could have occurred whether or not $\mathrm{Mr}$. Thornton used a motor vehicle," Thornton, 391 N.W.2d at 327, and followed this observation with a cf. cite to two cases, Saunders v. D etroit A utomobile Inter-Insurance Exch., 332 N.W .2d 613 (M ich. Ct. A pp. 1983), and M ann v. D etroit A utomobile Inter-Insurance Exch., 314 N.W .2d 719 (Mich. Ct. A pp. 1981), in which appellate courts had found that injuries were directly linked to the operation of a vehicle. See Thornton, 391 N.W.2d at 327. A s the Michigan Supreme Court acknowledged, '[i]n Thornton, the abbreviation 'Cf.' preceded cases that were being contrasted." M arzonie, 495 N.W.2d at 792 n.4.

117. See, e.g., supra note 20 and accompanying text (quoting from former Circuit J udge B ork's vehement dissent from a denial of rehearing en banc in H ohri v. United States, $793 \mathrm{~F} .2 \mathrm{~d}$ 304 (D.C. Cir. 1986)).

118. 644 A .2d 1373 (D.C. 1994) (per curiam).

119. See id. at 1373-74.

120. See id. at 1374.

121. 372 A .2d 998 (D.C. 1977).

122. 452 A .2d 354 (D.C. 1982).

123. See B ranch, 372 A .2d at 1000-01.

124. See Robinson, 452 A .2d at 357-58.

125. 456 U .S. 1, 8-9 (1982) (holding that the period between the dismissal of a first charge and a subsequent indictment is not within the comprehension of the Speedy Trial Clause). 
holding of M acD onald." 126 D espite the Givens majority's confusion regarding the use of the but cf. signal, the dissent recognized the distinction between the two cases:

In the parenthetical description following the citation to B ranch, the Robinson court stated that a "four and one-half month delay between dismissal of [a] charge and reindictment on [that] same charge counted for speedy trial clause purposes where dismissal [was] unrelated to investigative need on the original charge." . . . $[T$ ]his description of Branch distinguishes it from the facts of $M$ acD onald (initial charges dismissed when prosecutor concluded that allegations were untrue, indictment on same charges brought after further investigation), and could be read to indicate that the court would not apply $M$ acDonald to a case like Branch or the instant case, where the delays complained of are due to dismissal of indictments without prejudice for the convenience of the government. ${ }^{127}$

Readers of legal materials know the difficulty inherent in deciphering unexplained cf. citations. W e may not fault the judges for refusing to revive stillborn ideas, but surely the judiciary should not just ignore poorly conceived analogies. The clarity of the law suffers when published opinions fail to explain why proffered analogies must fail. E ven more importantly, our laws derive their legitimacy in part because we know why they are maintained. It is the function of the

126. G ivens v. U nited States, 644 A .2d 1373, 1374 n.3 (D.C. 1994) (per curiam).

127. Id. at 1376-77 ( $M$ ack, J., dissenting) (emphasis added) (citation omitted) (quoting Robinson, 452 A .2d at 357); see also Willingham v. Macon Tel. Publ'g Co., 482 F.2d 535, 541 n.4 (5th Cir. 1973) (Simpson, J ., dissenting) ("The single Court of A ppeals decision cited [in the majority opinion] under a 'cf.' . . . is completely inapposite ....."); J ohnson v. H arron, N o. 91CV -1460, 1995 W L 319943, at*12 \& n.15 (N.D.N.Y. M ay 23, 1995) (dismissing the defendants' cf. citation to U nited States v. E sieke, 940 F.2d 29 ( 2 d Cir. 1991), as inapposite because the facts in the instant case differed); Billing v. City of N orfolk, 848 F. Supp. 630, 635-36 (E .D. V a. 1994) (criticizing counsel's incorrect use of the cf. signal and refusing to rely on cases presented by the plaintiff, who claimed that the city deprived him of a liberty interest in private employment, in part because termination of employment was not present in one case); $\mathrm{M}$ aryland $\mathrm{C}$ as. $\mathrm{Co}$. v. W.R. G race \& Co., 794 F. Supp. 1206, 1214-15 (S.D.N.Y. 1991) (distinguishing, on factual grounds, the defendant's cf. citation to a case suggesting that, once triggered, a policy required insurers to defend the insured); In re Southern Int'I Co., 165 B.R. 815, 821 (Bankr. E.D. Va. 1994) (distinguishing between Fifth Circuit's cf. reference to In re A dkins, 28 B.R. 554 (B ankr. N.D. M iss. 1983), and the instant case by stating that the Fifth Circuit's decision was "meant to be binding only in those circumstances where the trustee ineffectively abandons property of the estate"); Illini FS, Inc. v. M yerscough, 484 N.E.2d 1385, 1388 (III. A pp. Ct. 1985) (concluding that a cf. citation lent support to the defendant's argument, and stating that "[d]espite the comparison made by the supreme court [of Illinois] we believe River Valley does not support plaintiff's argument. ... It is clear the supreme court was only concerned with the original tender which was refused not with the effect of the subsequent tender which was accepted."). 
judiciary to review citations and rail against analogies that they consider inapposite. Separating such flawed analogies from perfectly devious allusions (so-called "backhanded references" ${ }^{128}$ ) remains a subjective exercise, at least for the present.

4. N egative A uthority and Straw A nalogies. In legal discourse, as well as in life, chaotic situations often provide cover for subtle maneuvers. Unfortunately, the ambiguity and controversy surrounding the of. citation have led some legal writers to depart from The Bluebook's definition of the cf. citation as supporting authority and ascribe a contradictory value to the signal, showing extraordinary creativity in interpreting what they deem to be ambiguous cf. citations as negative authority. ${ }^{129}$ The result is that, in some cases, the cf. signal has been used as a lesser form of the but see signal. The infrequent use of the but $\mathrm{cf}$. signal ${ }^{130}$ use may also indicate that cf. is not interpreted as positive support in many cases. ${ }^{131}$

Consider, for example, the Ninth Circuit's decision in Campbell v. Wood. ${ }^{132} \mathrm{C}$ ampbell involved a habeas petitioner sentenced to death who challenged, inter alia, the constitutionality of execution by hanging. ${ }^{133}$ In denying his petition, the court used a cf. citation to G regg v. G eorgia, ${ }^{134}$ and stated that the proper constitutional standard for evaluating methods of punishment was "whether the method involves 'the unnecessary and wanton infliction of pain.'"135 In dissent, however, Judge Reinhardt criticized the majority for

128. See supra text accompanying note 85 .

129. See Czerkies v. U nited States Dep't of Labor, 73 F.3d 1435, 1447 (7th Cir. 1996) (E asterbrook, J ., dissenting) (disagreeing flatly with a citation by the $\mathrm{Ninth}$ Circuit in Rodrigues v. D onovan, 769 F.2d 1344 (9th Cir. 1985), and suggesting that the cited case should have been introduced with a contra, not a cf., signal).

130. A ccording to the sixteenth edition of The Bluebook, the but cf. signal should indicate that the " $[c]$ ited authority supports a proposition analogous to the contrary of the main proposition. The use of a parenthetical explanation of the source material's relevance ... following a citation introduced by 'but cf.' is strongly recommended." BLUEBOOK SIXTEEN, supra note 3 , R ule 1.2(c).

131. See, e.g., G eneral Elec. Co. v. Gilbert, 429 U .S. 125, 153 n.6 (1976) (Brennan, J., dissenting) (analyzing a "cryptic 'but cf.'" citation in the majority opinion); Walsh, supra note 5 , at 337 (examining the use of legal citations, and distinguishing between citations that are "weak" and those that are "strong").

132. 18 F.3d 662 (9th Cir. 1994).

133. See id. at 670.

134. 428 U.S. 153 (1976) (plurality opinion); see also Campbell, 18 F.3d at 682 n.11 (using a cf. signal to cite to $\mathrm{G}$ regg).

135. Campbell, 18 F.3d at 682 (quoting G lass v. Louisiana, 471 U.S. 1080, 1084 (1985) (B rennan, J., dissenting from a denial of certiorari)). 
abandoning traditional E ighth A mendment standards: "The majority cannot cite a single case in support of its astonishing and wholly unprecedented decision to bar the use of traditional Eighth A mendment concepts in cases involving forms of punishment, nor even a legal argument based on a remotely analogous case." ${ }^{136}$ In a footnote, Judge R einhardt continued: "[0]n the very same page as the passage the majority cites, the Gregg plurality made clear that 'excessiveness' is only one part of any E ighth A mendment analysis. Thus, excessive pain and disproportion are not the exclusive considerations in Eighth A mendment analysis." ${ }^{137}$ In effect, the majority had used a cf. citation to Gregg to eliminate one of the prongs of the $\mathrm{G}$ regg analysis.

When left unexplained, or only partially explained, the cf. citation is the signal that is the most vulnerable to unanticipated interpretations. Judges are effectively granted license to take the cited cases out of context. The signal thus absorbs some criticism from observers irritated at what they perceive as the use of Bluebook niceties to present slightly tweaked renditions of the same law. ${ }^{138}$ For example, during the course of the Iran-Contra A ffair litigation, D.C. Circuit Judge (now Chief Judge) Harry Edwards complained in his

136. Id. at 703 (R einhardt, J ., dissenting) (footnote omitted).

137. Id. at 703 n.19 (R einhardt, J ., dissenting).

138. See, e.g., Karl N. Metzner, Note, Retroactivity, Habeas Corpus, and the Death Penalty: A n U nholy A lliance, 41 D U KE L.J . 160, 172-73 (1991) (criticizing a distinction drawn in a cf. citation in Butler v. M cK ellar, 494 U .S. 407, 414 (1990), to United States v. L eon, 468 U.S. 897 (1984)). In Butler, a state prisoner attacked his conviction via a petition for federal habeas relief alleging that he had been interrogated after having requested counsel for a separate investigation. See Butler, 494 U.S. at 410 . The Court held that his claims were barred by the doctrine against retroactive application of new rules of constitutional criminal law announced in Teague v. L ane, 489 U.S. 288, 315 (1989) (O 'Connor, J., plurality opinion). See Butler, 494 U.S. at 415. The Court in Butler stated, "[t]he 'new rule' principle therefore validates reasonable, good-faith interpretations of existing precedents made by state courts even though they are shown to be contrary to later decisions." Id. at 414 . This statement was supported by a cf. citation to United States v. L eon, 468 U.S. at 918-19, with a parenthetical observing that the exclusionary rule should not "deter objectively reasonable law enforcement activity." Id.

In dissent, J ustice B rennan rejected this proposition and the authority it used for support:

The Court's analogy between the deterrent function of federal habeas and the deterrent function of the exclusionary rule ... is unsound, for the purported analogy continues to beg the question of what conduct ought to be deterred. . . . G iven the difference between the nature of police conduct at issue in Leon and judicial interpretation, the majority's proffered analogy is flawed. It ultimately does no more than borrow language from Leon, and ... . fails to justify the majority's decision to embrace a "reasonableness" test as the appropriate objective of state-court adjudication.

Id. at 425-26 n.6 (B rennan, J ., dissenting) (second emphasis added). 
opinion, In re Sealed Case, ${ }^{139}$ that Independent Counsel Lawrence $W$ alsh had not explained the nature of an analogical argument:

The Independent Counsel cites three cases for the proposition that personal jurisdiction over the individual served with a subpoena is enough to compel him to produce documents belonging to companies he represents. [H e] introduces these cases with the signal "Cf., e.g." Here, however, even that notoriously enigmatic signal has been taxed beyond its limits. We view with profound disfavor the Independent Counsel's disingenuous attempt to enlist prior holdings in the service of doctrines they in no wise support. ${ }^{140}$

A Ithough it is impossible to know what motivates legal writers to construe the cf. as negative authority, at least two unsavory possibilities exist. First, courts may deliberately misunderstand the original argument and invent negative analogies in order to obscure an author's intended analogies. Second, courts may create weak positive analogies-analogical straw men-whose patent lack of persuasiveness contributes to courts' contradictory rulings. N eedless to say, either insidious possibility subverts meaningful legal discourse. Likewise, because it is seen alternately as persuasive, unclear,

139. 832 F.2d 1268 (D.C. Cir. 1987). J udge E dwards ruled that the Independent Counsel had to demonstrate personal jurisdiction over certain companies (not merely upon the subpoenaed witness as a "custodian") in order to view their documents, stating that "[t]he Independent Counsel has adduced no authority to the contrary." Id. at 1273.

140. Id. at 1273 n.3 (emphasis added) (citation omitted). The court could not determine what analogies $L$ awrence $W$ alsh intended to draw:

It is hard to imagine what parallel the Independent Counsel purports to find .... A n analogy would exist were the Independent Counsel able to show that the Witness has done business in the $U$ nited States on behalf of the companies sufficient to give an A merican court jurisdiction over them, but [he] has not attempted to do so. ... A gain, the analogy the Independent Counsel apparently sees is elusive. The third case cited ... is even further off point .... .

Id.

This problem persists when litigants question cf. citations on appeal because courts can more easily articulate how they feel about a decision than why they feel that way. For example, in H unt v. Gan-Trade Corp., N o. H-89-2379, 1997 WL 314384 (S.D. Tex. M ar. 26, 1997), the court dealt with a challenge to a decision of the Interstate Commerce Commission on the ground that its action was arbitrary and capricious. See id. at $* 1$. The court disagreed because the Commission introduced a case on which it relied with a cf. signal:

This argument fails because the Commission only cited A moco Fabrics as "cf." authority .... A "cf." cite simply means that the cited case, while standing for a proposition different from the one stated, lends some support. The trustee does not attack the proposition for which the case was cited: only whether the case directly supports it. The Court finds that the case was sufficient as cited, and the Commission's decision was not rendered arbitrary and capricious as a result.

Id. at $* 3$ n. 2 . 
ignored, dismissed, or misunderstood, the cf. signal scrambles legal communications.

\section{The Cf. Signal: The CiPher to BetTer Understanding IN LEGAL DISCOURSE ${ }^{141}$}

\section{A. D ecoding B luebook Signals}

A s previously explained, legal semioticians can fashion codes that consolidate related signs to provide context for understanding and to illuminate the distinctive value or "preferred meaning" of a particular sign. ${ }^{142} \mathrm{U}$ nfortunately, however, the foregoing review of citation practice in the legal community suggests that, in reality, the use of the cf. signal is generally standardless. The only common denominator is that there is no common denominator. Considering the extent to which legal writers attempt to evince conformity with citation manuals such as The Bluebook, this conclusion suggests that these citation manuals fail to guide legal writers in a way that allows them to harness the cf.'s communicative potential. This Part considers why the signal definitions in The Bluebook-legal citation's prevailing code- fail to do so.

The sixteenth edition of The Bluebook identifies six signals that buttress propositions ([no signal], accord, see, see also, cf., ${ }^{143}$ and compare - the last of which is segregated as a "[s]ignal that suggests a useful comparison," ${ }^{144}$ for no apparent reason), two signals that introduce contradictory statements in the same manner (but see and but cf.), and two signals that inform the reader that other authorities discuss subject matter related to the proposition (see generally, and e.g. combined with any other signal). ${ }^{145}$ The Bluebook organizes these signals in groupings that range from "[s]ignals that indicate

141. Cf. Part I of this A rticle, supra, in which I intentionally avoided use of the cf. in my citations. Since the reader is now at the stage in this $A$ rticle at which the suggested rules of use for the cf. signal are outlined, use of the cf. is less ambiguous, and, therefore, I succumb. See generally Paulsen, supra note 2 , at 1791 (reviewing the fifteenth edition of The Bluebook as well as several other citation manuals and pointing out the irony of the "ever-changing uniform system of citation").

142. See supra notes $45-48$ and accompanying text.

143. See Bluebook Sixteen, supra note 3, Rule 1.2(a).

144. Id., Rule 1.2(b).

145. See id., Rule 1.2 . 
support"146 or "[s]uggest[] a useful comparison," ${ }^{147}$ to negative authority, ${ }_{1}^{148}$ background material, ${ }^{149}$ and other matters. ${ }^{150} \mathrm{~W}$ ithin each grouping, The Bluebook appears to order signals by weight. Signals attributing quotes ([no signal], accord) precede see, which "directly states or clearly supports the proposition." ${ }^{151}$ J ust as beauty lies in the eye of the beholder, the weight of an authority lies in the mind of the citation writer, and not merely because he or she often may employ a three-hundred-plus page manual for citation practice. The writer must make some representation concerning how strongly the cited authority supports the given proposition.

L egal writers are receiving strange messages. Consider that, after see, The Bluebook explains see also, which "constitutes additional source material that supports the proposition ... [and] is commonly used to cite an authority supporting a proposition when authorities that state or directly support the proposition already have been cited or discussed." 152 The see also signal presumably introduces authority of lesser weight because authorities so cited do not state or "clearly" support the proposition. Y et the inclusion of "also" in the signal's name implies that authors must find clear support for their propositions if no authority is mentioned in the text. Few writers use "also" as the first word of a new, pivotal paragraph. Furthermore, the definition assumes the presence of additional source material. E very writer's first source must therefore constitute clear support! This definition places pressure on legal writers to overstate their confidence in sources.

The Bluebook then turns to the nettlesome cf. signal, which it defines as follows: "Cited authority supports a proposition different from the main proposition but sufficiently analogous to lend support. Literally, 'cf.' means 'compare.' The citation's relevance will usually be clear to the reader only if it is explained. Parenthetical explanations .... however brief, are therefore strongly recommended." 153 This definition puts a new spin on the see also problem.

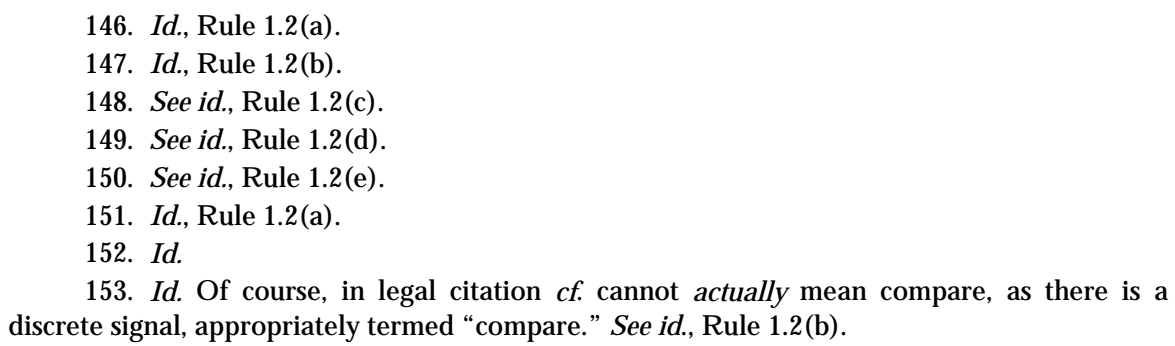


Whereas the see also definition appears to exert pressure on authors to characterize their strongest authority as clear support, from a deconstructive perspective the cf. signal's definition contains the premise that authority supporting only "a proposition different from the main proposition" cannot be clear support. This normative judgment denigrates the vital role of analogy in the understanding of law.

The current Bluebook code contains and transmits important messages about legal discourse. Under the guise of ordering signals by weight, The Bluebook subtly urges writers to inflate principal authorities and relegate analogical reasoning to the nether province of makeweight authority. Introductory signals assist in the transmission of complex legal discourse. They should be lighter than air. Or, at the very least, they should not carry this kind of baggage. We should consider a new series of definitions.

\section{B. N ew Signal D efinition and Citation Practice}

Clearly what writers need to agree to, in the search for a consistent ${ }^{154}$ and meaningful cf. citation, is a systematized approach to its use. The cf. signal should be used when providing support that is "sufficiently analogous" to the proposition stated. ${ }^{155}$ A general cf. citation to an entire case can lead the reader to create his or her own analogy by searching through the text of the judicial opinion for meaning from the cf. reference, and to speculate about the weight

154. Seldom is Emerson's trenchant warning more appropriate than with regard to signals used in legal discourse: "a foolish consistency is the hobgoblin of little minds." RALPH WALDO EMERSON, Self-Reliance, reprinted in 2 THE COMPLETE WORKS OF RALPH WALDO EMERSON 43, 57 (1903) (emphasis added); see also A LDISERT, supra note 40, $\S 9.2$, at 132 (arguing that ensuring consistency in judicial decisionmaking is a key to the value of stare decisis).

155. BLUEBOOK SIXTEEN, supra note 3, Rule 1.2(a). A nalogical reasoning underpins the value in, and meaning behind, using introductory signals at all. In fact, analogy "makes possible a new kind of reasoning which leads to an innovative representation." L adeur, supra note 40 , at 17 (footnote omitted). "[A ]nalogy signals a moment of invention, based on the understanding of the concrete situation, which resists the logical-syntactical paradigm of deduction." Id. at 18 (footnote omitted). A nalogy is governed "by the principle of legal equality, which dictates that different cases with the same essential features are to be disciplined using the same treatment." Giuseppe Zaccaria, Analogy as Legal Reasoning, in LEGAL KNOWLEDGE AND LEGAL A NA LOGY, supra note 40 , at 55 (footnotes omitted).

Zaccaria goes on to discuss the criticism that analogical reasoning is "unscientific because of its insufficient precision." Id. at 56 . Even accepting that perfect precision in any analytical written work is unlikely to be attained, albeit continually striven for, some increased consistency in the forms attached to analogical reasoning can certainly be encouraged. See id. 
that any inferred analogy should be given. While this sort of general reference may be the express intention of the legal writer, ${ }_{1}^{156}$ it is equally likely to mask a more esoteric phenomenon: lack of intellectual rigor in finding support for the main proposition. $G$ eneral cf. citations, or more troubling cf. usage that offers an inaccurate citation to the proposition cited, ${ }^{157}$ fosters an atmosphere in which imprecision becomes the byword in the use of the cf. Such a situation is intolerable if the cipher is to be clarified and the law and its development are to have fair meaning. The power of interpretation may well lead to misapprehension and ultimately to signal loss, particularly when the meaning of a citation is obscure and inscrutable. This lamentable eventuality defeats the primary purposes of having signals at all, which are to enable access to materials, to indicate the weight accorded to authority, and to prompt the author and reader to analyze the relevance of citation questions. ${ }^{158}$

156. A mbiguity may be inevitable in judicial decisionmaking; it might also be good. See $\mathrm{H}$ alpern, supra note 75, at 41 (presenting as one option in analysis of the Supreme Court's lack of use of a parenthetical or pinpoint cite in Stone v. Powell, 428 U.S. 465 (1976), that the majority may well have deliberately omitted a clear referent; they may have wanted the lower courts to determine for themselves the factors involved in measuring whether a "full and fair hearing" was given).

This A rticle focuses on semiotics as a theoretical construct to analyze signals as signs or codes through which legal discourse occurs. A nother approach-deconstruction-could provide some explication of deliberate vagueness in citation usage. D econstruction is "a movement that insists that the gaps and corners and slippages in texts-the words not chosen-are as important to its meaning as the 'central ideas' studied in traditional forms of interpretation." Coombs, supra note 2, at 1100; see also id. at 1100 n.5 (citing JA CQUES DERRIDA, OF GRAMMATOLOGY (1976)). Thus cf. usage can be as important for what it does say (when an explanatory parenthetical phrase is added) as for what it does not say (when the citation is left unexplained). Further application of deconstruction to the nuances of cf. practice is beyond the scope of this A rticle.

157. See supra notes $129-40$ and accompanying text (discussing judicial decisions that either use cf. as negative authority or that take that signal completely out of context); see also M etzner, supra note 138, at 170-74 (discussing Butler v. M cK ellar, 494 U .S. 407 (1990)). This case provides an excellent example of disagreement in interpretation between majority and dissent, such that the latter accuses the former of citing a case out of context. See Butler, 494 U.S. at 419-21. The dissent in Butler believed that the connection between the deterrent function of the exclusionary rule on police and the deterrent function of habeas corpus on state courts was a tenuous one. See id. at 425 n.6 (Brennan, J., dissenting); see also supra note 138 (quoting the dissent at length). Thus, even where a parenthetical is used, it is key that the writer be explicit about the meaning the reader ought to glean from the citation; otherwise, the law remains undefined, and the cipher remains intact.

158. See WEINER, supra note 18, at 223 (analyzing the "virtually cryptographic code" used to signal what weight, if any, should be given to a particular citation); Coombs, supra note 2 , at 1105-06, 1110 (depicting the purpose of citations as providing a reference point for further research and claiming that standard citation forms use linguistic ambiguity in order to avoid making strong and exacting analogies); D ickerson, supra note 2, at 69 (stating that authors use 
R egarding the of. signal, R ule 1.2(a) of the sixteenth edition of The B luebook posits: "The citation's relevance will usually be clear to the reader only if it is explained. Parenthetical explanations .... , however brief, are therefore strongly recommended." ${ }^{159}$ There are at least three possible approaches to tackling the problems inherent in the current state of cf. usage. First, the citation rule could remain exactly as it is. Thus, parentheticals, "however brief," 160 would continue to be strongly recommended. This solution is inadequate, because it merely recommends and does not mandate parentheticals. It was, in fact, the recommendation in both the fifteenth and sixteenth editions of The Bluebook. Indeed, L ambrix v. Singletary ${ }^{161}$ came down from the Supreme Court after the sixteenth edition had already been published, and yet the Court included no parenthetical explanation for its of. citation. Thus, a strong recommendation still may not address documented signal loss.

The second approach goes one step further. Parenthetical explanations should continue to be strongly recommended; in addition, the recommendation would state that parentheticals should be both relevant and substantive. This rewording would solve many, but not all, of the problems associated with use of the cf. signal. Notably, an author's intention would be more clearly delineated, which consequently would minimize the searches for meaning undertaken by readers looking for greater precision in judicial decisionmaking. If the writer chose to ignore this strong recommendation, however, the reader again would be in a position to interpret the citation as he or she chose. This reform does not proscribe deliberate vagueness. $R$ ather, it clarifies that unexplained citations actually represent undecided and inconstant elements in the law. B ut this solution falls short of eliminating the problem caused by current usage of the cf. signal.

This A rticle recommends a third approach. Parenthetical explanations should not only be both relevant and substantive, but they should also be mandatory. This approach minimizes the disconnect between authors and readers when, for example, a pinpoint citation is given, but no explanation of its relevance is

signals to indicate the weight to be accorded to a given authority). But see $\mathrm{W}$ alsh, supra note 5 , at 338 (stating that "citations potentially open a window to better understanding of judicial decisionmaking").

159. BLUEBook SiXteEn, supra note 3 , Rule 1.2(a).

160. Id. (emphasis added).

161. See supra notes 9-17 and accompanying text (discussing $L$ ambrix). 
mentioned. Rule 1.2(a) of The Bluebook should explicitly promote this goal of reasoned elaboration, rather than implicitly downplay the role of analogical reasoning in legal discourse.

In accordance with the foregoing discussion, I recommend the following revisions (with additions underlined and deletions indicated) to assist in clarifying the connection between citation signals and analogical legal reasoning. For completeness, I include recommended changes not only for the cf. signal, but also for other signals where appropriate for clarity or consistency. R ule 1.2 should read as follows:

\section{Introductory Signals}

\section{(a) Signals that indicate support.}

[no signal] Cited authority (i) identifies the source of a quotation, or (ii) identifies an authority referred to in text.

A ccord "Accord" is commonly used when two or more cases clearly support the proposition but the text quotes only one; the others are then introduced by "accord." Similarly, the law of one jurisdiction may be cited as being in accord with that of another.

See

Cited authority directly states or clearly supports the proposition.

See also Cited authority constitutes additionat less significant source material that nonetheless clearly supports the proposition. "See also" is commonly used to cite an authority supporting a proposition when the most significant authorities that directly state or directly clearly support the proposition already have been cited or discussed. The use of a parenthetical explanation of the source material's relevance (rule 1.5) following a citation introduced by "see also" is encouraged strongly recommended. 
Cf. Cited authority supports a proposition different from the main proposition but is sufficiently analogous to lend support to the proposition. titerally, "ef." means eompare. Parenthetical explanations (rule 1.5), however brief, are therefore strongly recommended. should be employed because The citation's the authority's relevance will usually be clear to the reader only if it is explained. Unexplained "cf." citations may be construed generously by the reader.

Compare... Comparison of the authorities cited will offer support [and] ... for or illustrate the proposition. The relevance of the with ... comparison will usually be clear to the reader only if it [and]... is explained. Parenthetical explanations (rule 1.5) following each authority are therefore strongly recommended.

\section{(c) (b) Signals that indicate contradiction.}

But see $\quad$ Cited authority directly states or clearly supports a proposition contrary to the main proposition. "But see" is used where "see" would be used for support.

Butcf. $\quad$ Cited authority supports a proposition analogous to the contrary of the main proposition. The use of a parenthetical explanation of the source material's relevance (rule-1.5) following a citation introduced by "but cf." is strongly recommended. Parenthetical explanations (rule 1.5), however brief, should be employed because the authority's relevance will be clear to the reader only if it is explained. U nexplained "but cf." citations may be construed generously by the reader.

These proposed definitions would obviate many of the problems associated with current cf. usage. The proposed explanation of the cf. signal ties creation of a mandatory parenthetical to the quality of the legal reasoning used.

If the goals of judicial decisionmaking include clarity and avoidance of ambiguity, then controlled ambiguity should be the 
byword of opinion writers and Bluebook watchdogs. With controlled ambiguity-in which the writer determines, through explanatory parentheticals, the extent of reliance that he or she intended to convey-I believe that taking the reader through a reasoning process or pointing the reader in the direction in which the writer wants future readers to go will have numerous benefits. It will minimize undue discretion in the hands of the frustrated reader, lead the opinion writer to greater understanding by forcing him or her to justify the reasoning employed, encourage greater adherence by the reader to whatever principle or precedent the writer intended to allude, and ultimately result in a minimization of signal loss.

\section{CONCLUSION}

Introductory legal citation signals have been criticized for obscuring, rather than enlightening, the relevance of cited materials. Where a signal is used incorrectly, misapprehension is inevitable. E qually problematic, however, is signal use that leads to unintended ambiguous interpretation by the reader. This A rticle brings to light how one seemingly trivial legal citation signal, the cf., has been used in judicial decisions-sometimes helpfully, but typically not. Improper usage has led to frustrating (but colorful) commentary from legal writers and thinkers as they try to decipher precedent. For example:

- O ne can only wonder what proposition 'sufficiently analogous' to the quoted proposition derives support from [the precedent cited]. ${ }^{162}$

- The temptation to exaggerate a decision with which one disagrees, thereby to make it an easy target for slings and arrows, ought to be resisted. ${ }^{163}$

- The Court's analogy between the deterrent function of federal habeas and the deterrent function of the exclusionary rule ... is unsound[;] ... the majority's proffered analogy is flawed. ${ }^{164}$

162. W olgin v. M agic M arker Corp., 82 F.R.D. 168, 174 n.1 (E .D. Pa. 1979)

163. H ohri v. U nited States, 793 F.2d 304, 315 n.3 (D.C. Cir. 1986) (statement of W right \& G insburg, J J ., citing D ronenberg v. Zech, 746 F.2d 1579, 1582-84 (D.C. Cir. 1984) (en banc) (separate statement of B ork, J.)).

164. B utler v. M cK ellar, 494 U .S. 407, 425-26 n.6 (1990) (B rennan, J ., dissenting). 
- [The cited case] is not entirely on point, although the Court does not explain what distinction it has in mind. ${ }^{165}$

- In [a previously cited case], the abbreviation "cf." preceded cases that were being contrasted. ${ }^{166}$

- Here, ... even that notoriously enigmatic signal has been taxed beyond its limits... . [and the court] view[s] with profound disfavor the ... attempt to enlist prior holdings in the service of doctrines they in no wise support. ${ }^{167}$

Given the inconsistent approach to and considerable confusion associated with cf. usage-best exemplified by those cases that actually use the cf. as negative authority, completely ignoring many generations of Bluebook definitions declaring it to be positive authority-the very integrity of legal reasoning by analogy is at stake.

O ne commentator neatly summarized a constructive approach to improved citation writing: "Sure, there are problems with law review footnotes, but let's just roll up our sleeves and take care of them." ${ }^{168}$ The solution to the problems of the cf. signal is mandatory parenthetical explanations or elaborations that are both relevant and substantive. The benefits of this approach, as well as of accurate and consistent signal use generally, are many: jurisprudence is more definite, because explanations for having cited a particular precedent are readily at hand; writers' intentions are clearer, because an analogy is attached to the cited authority; and readers' attempts to create their own analogies, or to vary weight assigned to a given citation, are thwarted by the existence of relevant and substantive mandatory parentheticals. These benefits ultimately will result in better guidance to judges, lawyers, and litigants, as well as in a broader understanding of judicial decisionmaking. M ost importantly, tightening the definition of the of. signal, along with the rules for its use, will help to preserve the primary pillar of common law jurisprudence: reasoning by analogy.

165. Parren v. State, 523 A .2d 597, 609 (M d. 1987).

166. M arzonie v. A uto Club Ins. A ss'n, 495 N.W.2d 788, 792 n.4 (M ich. 1992).

167. In re Sealed Case, 832 F.2d 1268, 1273 n.3 (D.C. Cir. 1987).

168. Patrick M. M cFadden, Fundamental Principles of A merican L aw, 85 CAL. L. REv. 1749, 1750 (1997). M CFadden then supported his supposition with a creative cf. reference: "Cf. PLACES IN THE HEART (Tri-Star 1984) (former flying nun does what it takes to bring in the cotton and save the farm)." Id. at n.3. 